\title{
Unravelling the Potamonautes lirrangensis (Rathbun, 1904) species complex (Potamoidea: Potamonautidae), with the description of two new species
}

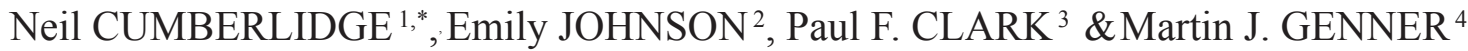 \\ ${ }^{1,2}$ Northern Michigan University, Biology, 1401 Presque Isle Avenue, Marquette, \\ Michigan 49855, USA. \\ ${ }^{3}$ Department of Life Sciences, Natural History Museum, Cromwell Road, London SW7 5BD, UK. \\ ${ }^{4}$ School of Biological Sciences, University of Bristol, Bristol, BS8 1TQ, UK. \\ *Corresponding author: ncumberl@nmu.edu \\ ${ }^{2}$ Email: emiljohn@nmu.edu \\ ${ }^{3}$ Email: p.clark@NHMUK.ac.uk \\ ${ }^{4}$ Email: m.genner@bristol.ac.uk \\ ${ }^{1}$ urn:1sid:zoobank.org:author:05F6365E-D168-4AE3-B511-80FA7E31ACC1
${ }^{2}$ urn:1sid:zoobank.org:author:E200E21D-605E-4AEB-BF9D-9227FF185931
${ }^{3}$ urn:lsid:zoobank.org:author:BB4A2E90-621A-40BB-A90C-FFDCEE71A4E9
${ }^{4}$ urn:lsid:zoobank.org:author:51EC6157-05BE-41A3-AD99-28107E6F8B5B
}

Abstract. The taxonomic status of the widely distributed freshwater crab Potamonautes lirrangensis (Rathbun, 1904) sensu lato is revised because morphological and molecular evidence indicates that this taxon is a complex comprising more than one species. Four taxa are now recognized: Potamonautes lirrangensis (Rathbun, 1904) s. str. and P. kisangani sp. nov. from the Middle Congo River in Central Africa, P. amosae sp. nov. from the drainages of Lakes Kivu and Tanganyika, and P. orbitospinus (Cunnington, 1907) from Lake Malawi which had been previously synonymised with $P$. lirrangensis s. lat. Diagnoses, illustrations and distribution maps are provided for each of these taxa and they are compared to similar species from Central and Southern Africa.

Keywords. Freshwater crabs, Africa, Potamonautes amosae sp. nov., P. kisangani sp. nov., P. orbitospinus (Cunnington, 1907), revision, taxonomy.

Cumberlidge N, Johnson E., Clark P.F. \& Genner M.J. 2021. Unravelling the Potamonautes lirrangensis (Rathbun, 1904) species complex (Potamoidea: Potamonautidae), with the description of two new species. European Journal of Taxonomy 744: 145-178. https://doi.org/10.5852/ejt.2021.744.1309

\section{Introduction}

This work focuses on the taxonomic status of the widely distributed species Potamonautes lirrangensis (Rathbun, 1904) s. lat., which has a reported range that includes the Middle Congo River (Rathbun 1904, 1921; Capart 1954), Lake Kivu (Chace 1942; Bott 1955; Reed \& Cumberlidge 2006; Cumberlidge \& Meyer 2011; Daniels et al. 2015), rivers near Lake Tanganyika, Tanzania (Marijnissen et al. 2006; 
Reed \& Cumberlidge 2006), Lake Tanganyika (Capart 1952; Coulter 1991; Marijnissen et al. 2006; Reed \& Cumberlidge 2006), and Lake Malawi (Balss 1929; Chace 1942; Bott 1955; Marijnissen et al. 2006; Reed \& Cumberlidge 2006; Cumberlidge \& Meyer 2011; Kochey et al. 2017). The study was prompted by doubts regarding the continued inclusion of the large number of specimens currently attributed to $P$. lirrangensis s. lat. from widely separated parts of Africa on the basis of only a few morphological characters.

The original description of Potamon (Potamon) lirrangensis was based on a single dried adult female specimen (carapace width (CW) $43.7 \mathrm{~mm}$ ), which is now in poor condition, collected in 1891 from Liranga in the Middle Congo River in the République du Congo (Fig. 1). Thirteen years later, Rathbun (1904: pl. VI fig. 8) described the species from this specimen and unfortunately, since 1904 there has been no new material collected from the type locality. Despite this, subsequent authors (Rathbun 1921; Balss 1929; Chace 1942; Bott 1955; Reed \& Cumberlidge 2006; Cumberlidge \& Meyer 2011) have assigned superficially similar specimens from elsewhere in Central Africa (Fig. 1) and the Rift Valley lakes (Figs 2-3) to Potamonautes lirrangensis s. lat. based on the limited set of characters available from the adult female type. Among these were specimens from Lake Malawi (Fig. 2) that had previously been described as Potamon (Potamonautes) orbitospinus Cunnington, 1907, a taxon that Balss (1929, 1936) and Chace (1942) accepted, but which Bott (1955) treated as a junior synonym of Potamonautes lirrangensis s. lat. This opinion was followed by subsequent authors (Coulter 1991; Reed \& Cumberlidge 2006; Ng et al. 2008; Cumberlidge \& Meyer 2011).

The taxonomic status of $P$. lirrangensis and $P$. orbitospinus is reviewed here from the results of recent morphological and molecular studies of freshwater crabs from the entire range of $P$. lirrangensis $\mathrm{s}$. lat. including the D.R. Congo (Fig. 1), western Tanzania, and Lakes Tanganyika, Kivu (Fig. 3), and Malawi (Fig. 2; Marijnissen et al. 2006; Reed \& Cumberlidge 2006; Cumberlidge \& Meyer 2011; M. Genner, unpubl. data). These works indicate that $P$. lirrangensis $\mathrm{s}$. lat. as presently configured is not monophyletic, and comprises a species complex.

In the present study the taxonomically important characters of 83 specimens currently attributed to P. lirrangensis s. lat. are compared from 15 localities representing the known range of this species together with available molecular evidence (Marijnissen et al. 2006; Daniels et al. 2015). The results collectively indicate that $P$. lirrangensis s. lat. comprises at least 4 species: $P$. lirrangensis s. str., with a distribution restricted to the Middle Congo River in the République du Congo, P. kisangani sp. nov. from Kisangani in the D. R. Congo, P. amosae sp. nov. from the basins of Lakes Kivu and Tanganyika, and $P$. orbitospinus from Lake Malawi. These taxa are described and illustrated, updated distribution maps are provided, and their conservation status is discussed in the light of the new data provided here.

\section{Material and methods}

\section{Morphological analyses}

Eighty-three specimens were examined from the Middle Congo River (Liranga, Kisangani; Fig. 1), rivers near Lake Tanganyika, Tanzania, and Lakes Kivu, Tanganyika (Fig. 3), and Malawi (Fig. 2) (Table 1) that had been attributed to either $P$. lirrangensis s. lat. or to $P$. (P.) orbitospinus. Morphological analyses included a detailed examination of characters of the carapace, thoracic sternum, mouthparts, chelipeds, pereiopods, and gonopods. The habitats at the collection localities of the specimens attributed to P. lirrangensis s. lat. range from major rivers to deep African Rift Valley lakes. Measurements were made with digital callipers and are given in millimetres $(\mathrm{mm})$. The habitus and gonopod photographs were taken with a digital camera and a Keyence VHX 5000 digital microscope (Keyence, Itasca, IL, USA), and post processing was undertaken using Adobe Photoshop CC 2015.0.1 Release. Measurements of the subterminal articles (SA) of gonopods 1 and $2(\mathrm{G} 1, \mathrm{G} 2)$ were made along a straight line beginning 
at the midpoint of the basal margin and ending at the midpoint of the distal margin (at the junction between the two parts). Measurements of the terminal articles (TA) of G1 and G2 were made on the ventral face along the midline beginning at the midpoint of the basal margin that forms the SA/TA junction and ending at the TA tip. The length of the TA of G1 and G2 relative to the length of the SA of each of these structures is presented as the ratio of the terminal article/subterminal article (TA/SA). Adult females were recognized by their conspicuously widened pleon whose lateral margins (A4-6) cover the episternites of the thoracic sternum; a telson which covers the anterior thoracic sternum (S1-4) and by the 4 pairs of broad feathery biramous pleopods on pleomeres 2-5. Adult female specimens may or may not be carrying eggs or hatchlings in the pleonal brood pouch. The beginning of the adult size range is indicated by females with a $\mathrm{CW}$ that is either equal to, or greater than, the $\mathrm{CW}$ of the smallest known adult female (Cumberlidge 1999; Marijnissen et al. 2006). This value for females was used here

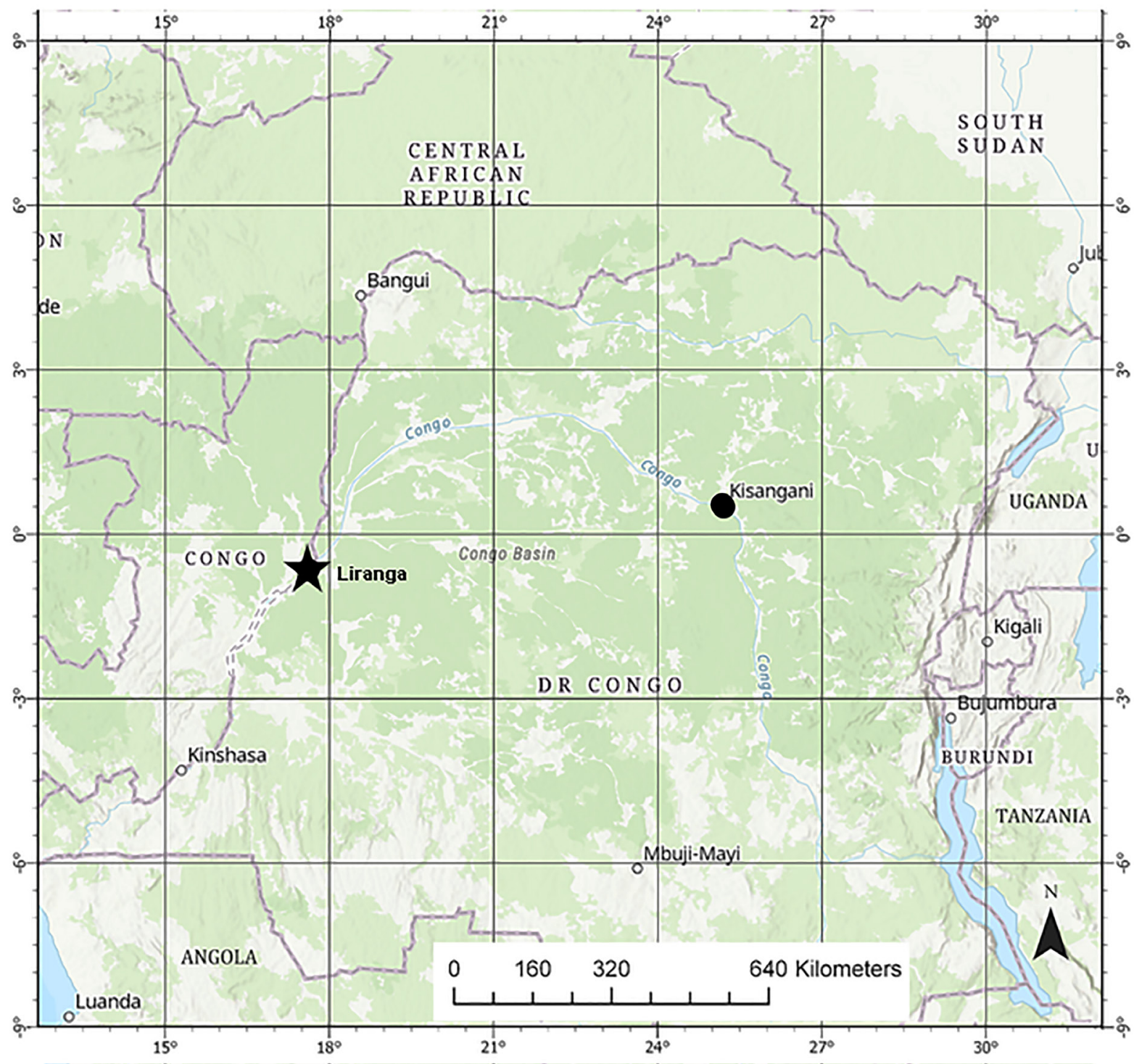

Fig. 1. Map showing the updated geographic distribution of Potamonautes lirrangensis (Rathbun, 1904) s. str. The black star on the left is Liranga, République du Congo (MNHN B-3826), the type locality. The black circles show the distribution of Potamonautes kisangani sp. nov. in the vicinity of Kisangani, D.R. Congo. See text for exact localities. 


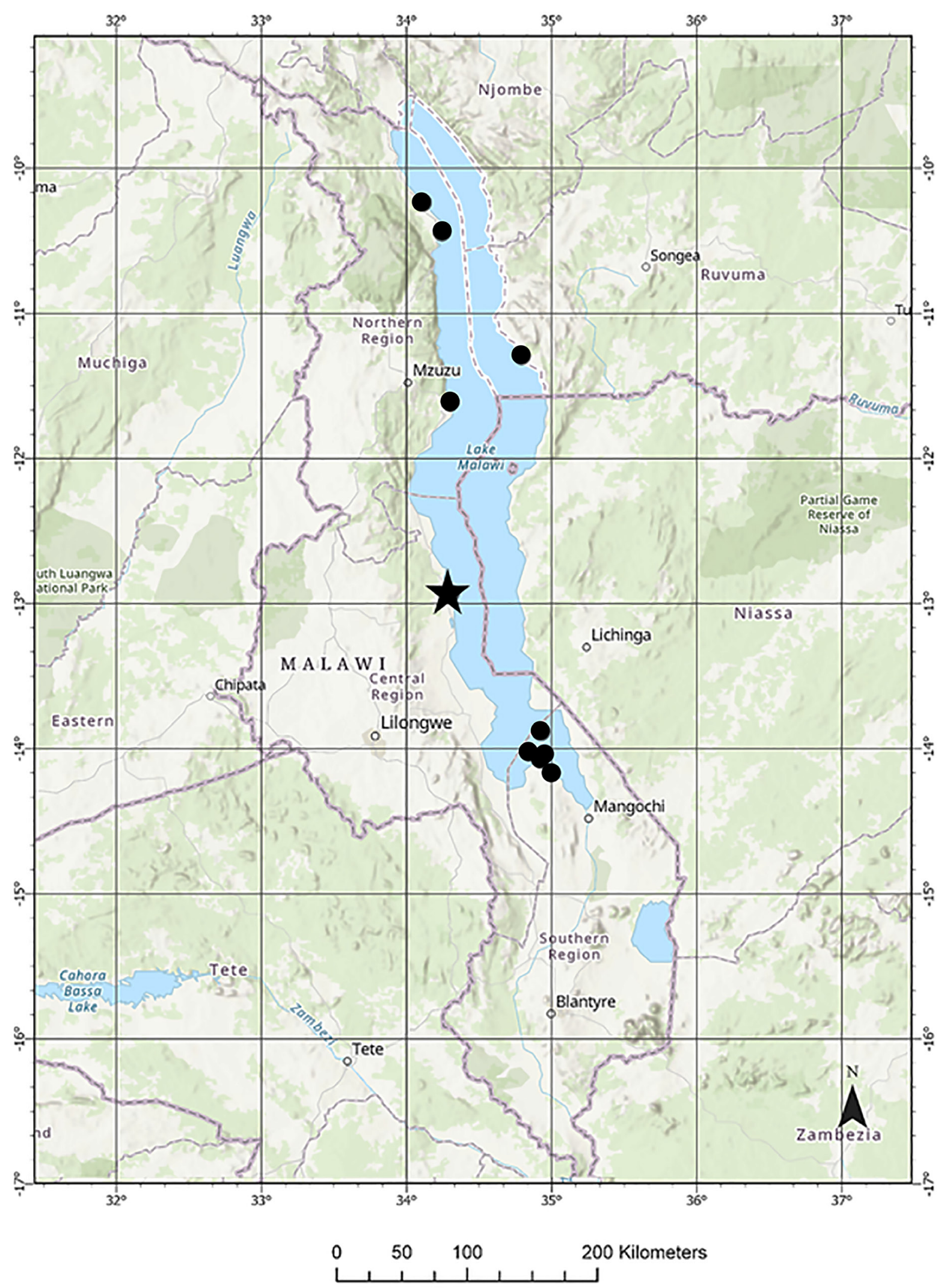

Fig. 2. Map showing the updated geographic distribution of Potamonautes orbitospinus (Cunnington, 1907). The black star shows the type locality. See text and Table 2 for exact localities. 
to establish the beginning of the adult size range for male specimens. The terminology is adapted from Cumberlidge (1999) and the higher classification used follows that of $\mathrm{Ng}$ et al. (2008).

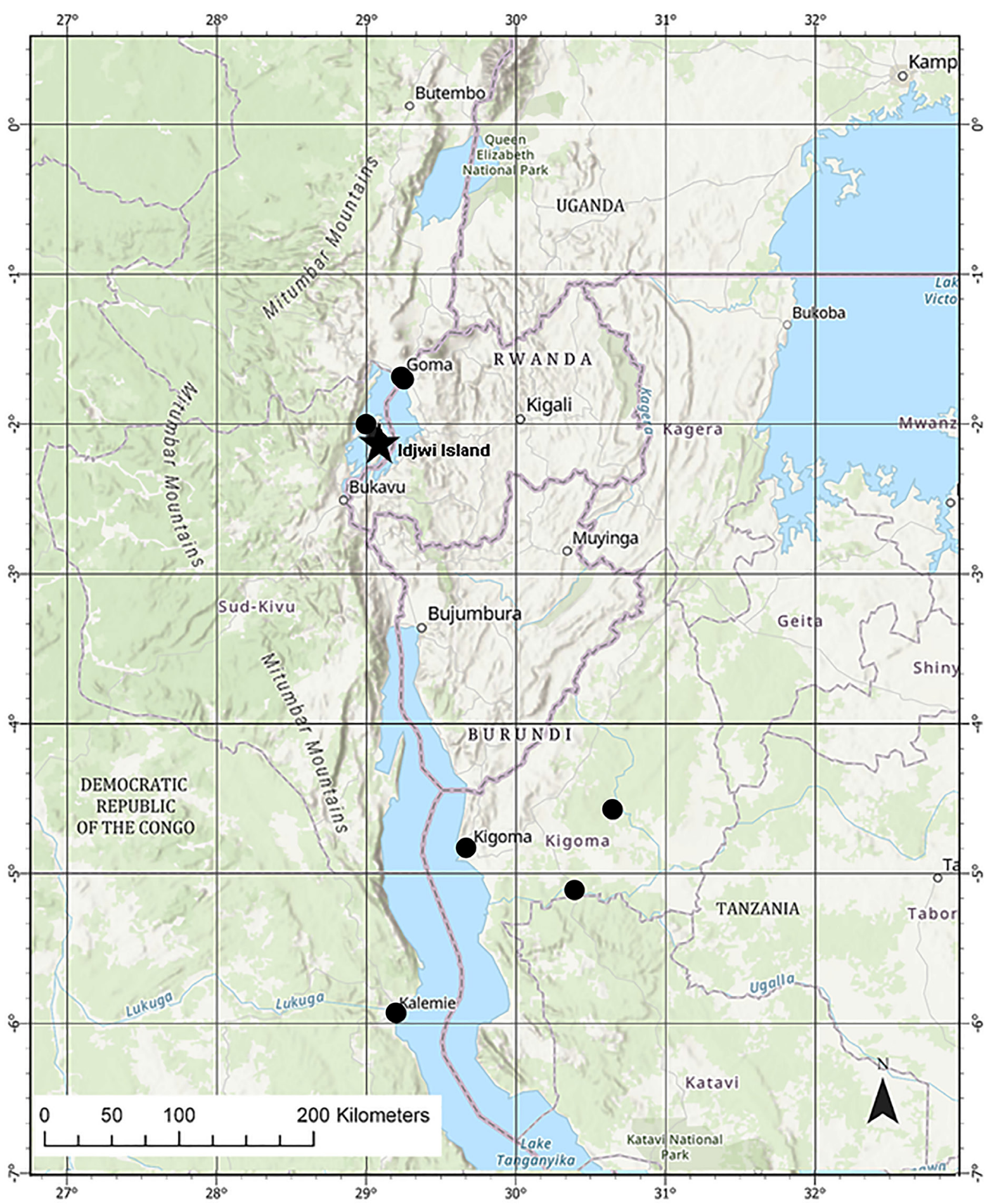

Fig. 3. Map showing the updated geographic distribution of Potamonautes amosae sp. nov. The black star shows the type locality. See text for exact localities. 
Table 1. History of the description of the first gonopod (G1) of specimens of Potamonautes lirrangensis (Rathbun, 1904) s. lat. with the revised identifications in the present work.

\begin{tabular}{|c|c|c|c|c|c|}
\hline $\begin{array}{c}\text { Revised } \\
\text { identification }\end{array}$ & $\begin{array}{c}\text { Previous } \\
\text { identification }\end{array}$ & Specimen & G1 Illustrated & Country & Locality \\
\hline $\begin{array}{l}\text { P. lirrangensis } \\
\text { (Rathbun, 1904) } \\
\text { s. str. }\end{array}$ & $\begin{array}{l}\text { P. lirrangensis } \\
\text { (Rathbun, 1904) } \\
\text { s. lat. }\end{array}$ & Holotype & None & $\begin{array}{l}\text { République du } \\
\text { Congo }\end{array}$ & Liranga \\
\hline $\begin{array}{l}\text { P. kisangani } \\
\text { sp. nov. }\end{array}$ & $\begin{array}{l}\text { P. lirrangensis } \\
\text { (Rathbun, 1904) } \\
\text { s. lat. }\end{array}$ & Holotype & $\begin{array}{l}\text { Rathbun (1921: fig. 8g); } \\
\text { present work Fig. 11A }\end{array}$ & D.R. Congo & Kisangani \\
\hline P. amosae sp. nov. & $\begin{array}{l}\text { P. lirrangensis } \\
\text { (Rathbun, 1904) } \\
\text { s. lat. }\end{array}$ & $\begin{array}{c}\text { Holotype NHMUK } \\
2018.306\end{array}$ & $\begin{array}{l}\text { Present work } \\
\text { Fig. 11B-H }\end{array}$ & Rwanda & Lake Kivu \\
\hline P. amosae sp. nov. & $\begin{array}{l}\text { P. lirrangensis } \\
\text { (Rathbun, 1904) } \\
\text { s. lat. }\end{array}$ & $\begin{array}{c}\text { Non-type MCZ } \\
11224\end{array}$ & Chace (1942: fig. 1b) & D.R. Congo & $\begin{array}{l}\text { Lake Kivu, } \\
\text { Idjwi Island }\end{array}$ \\
\hline P. amosae sp. nov. & $\begin{array}{c}\text { P. lirrangensis } \\
\text { (Rathbun, 1904) } \\
\text { s.lat. }\end{array}$ & $\begin{array}{c}\text { Non-type MCZ } \\
32878\end{array}$ & Bott (1955: figs 38-39) & Rwanda & $\begin{array}{l}\text { Lake Kivu, } \\
\text { Goma }\end{array}$ \\
\hline P. amosae sp. nov. & $\begin{array}{l}\text { P. lirrangensis } \\
\text { (Rathbun, 1904) } \\
\text { s.lat. }\end{array}$ & $\begin{array}{l}\text { Non-type NMU } \\
\text { TRW1972.04 }\end{array}$ & $\begin{array}{l}\text { Reed \& Cumberlidge } \\
\text { (2006: figs } 153-154, \\
\text { pl. 5c) }\end{array}$ & Tanzania & $\begin{array}{l}\text { Kigoma, } \\
\text { Malagarasi } \\
\text { River }\end{array}$ \\
\hline $\begin{array}{c}\text { P. orbitospinus } \\
\text { (Cunnington, 1907) }\end{array}$ & $\begin{array}{l}\text { P. lirrangensis } \\
\text { (Rathbun, 1904) } \\
\text { s. lat. }\end{array}$ & $\begin{array}{l}\text { Non-type NMU } \\
\text { TRW } 1972.05\end{array}$ & $\begin{array}{l}\text { Cumberlidge \& Meyer } \\
\text { (2011: fig. 7a-b) }\end{array}$ & Malawi & Lake Malawi \\
\hline $\begin{array}{c}\text { P. orbitospinus } \\
\text { (Cunnington, 1907) }\end{array}$ & $\begin{array}{l}\text { P. lirrangensis } \\
\text { (Rathbun, 1904) } \\
\text { s. lat. }\end{array}$ & $\begin{array}{c}\text { Lectotype } \\
\text { NHMUK } \\
1908.1 .31 .27\end{array}$ & $\begin{array}{l}\text { Present work } \\
\text { Fig. 11A-D }\end{array}$ & Malawi & $\begin{array}{l}\text { Nkhata Bay, } \\
\text { Lake Malawi }\end{array}$ \\
\hline
\end{tabular}

\section{Molecular and phylogenetic analyses}

Tissue was harvested from either the gills or the ambulatory legs of ethanol preserved specimens. DNA was extracted using a DNeasy kit (Qiagen, Hilden, Germany), following the protocol of the manufacturer. One mitochrondrial (16S rRNA) and one nuclear (histone 3, H3) locus were sequenced, using the primers 16SA and 16SB (Palumbi et al. 1991), and H3AF and H3AR (Colgan et al. 1998), as reported in Daniels et al. (2015). PCR reactions were conducted in $25 \mu \mathrm{L}$ volumes, including $12.5 \mu \mathrm{L}$ of MyTaq mastermix (Bioline, London), $0.5 \mu \mathrm{L}$ of each primer $(10 \mathrm{mM}), 11 \mu \mathrm{L}$ molecular grade water, and $1 \mu \mathrm{L}$ of template DNA (1:10 dilution of eluted DNA). PCR conditions were as follows: 1 minute at $95^{\circ} \mathrm{C}$, then 35 cycles of $95^{\circ} \mathrm{C}$ for $30 \mathrm{~s}, 50^{\circ} \mathrm{C}$ for $30 \mathrm{~s}$ and $72^{\circ} \mathrm{C}$ for 1 minute, followed by $72^{\circ} \mathrm{C}$ for 5 minutes. Amplification success was checked on 1\% agarose gel. Purification and sequencing of the PCR products was outsourced to either Macrogen (Seoul, Korea) or Eurofins Genomics (Wolverhampton, UK). Sequences were checked using Chromas ver. 2.6 (Technelysium Ltd, Brisbane), and novel sequences have been deposited in GenBank (Table 2).

Sequences were aligned using ClustalW (Thompson et al. 2003), and concatenated in SequenceMatrix (Vaidya et al. 2011). The phylogenetic analyses utilised both the $16 \mathrm{~S}$ and $\mathrm{H} 3$ genes. Maximum Likelihood (ML) analyses were conducted in IQ-TREE ver. 2.12 (Minh et al. 2020), on the IQ-TREE webserver, using an automatic model selection including the 16S locus as one partition, and each codon position of the H3 genes as separate partitions (Chernomor et al. 2016). Branch support was estimated from 1000 


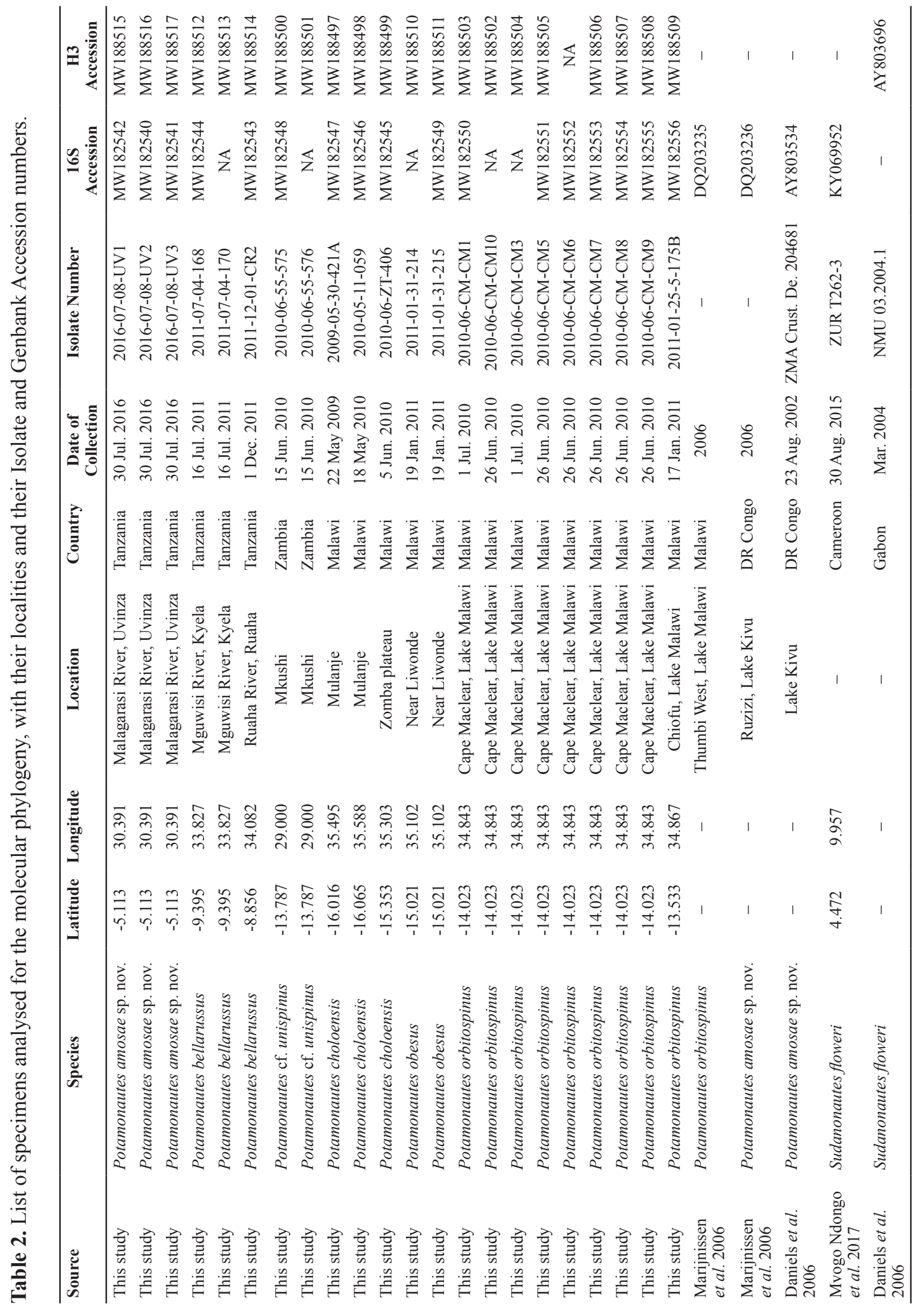


ultrafast bootstrap replicates (Hoang et al. 2018). Only bootstrap proportions $>70 \%$ were regarded as strongly supported. Bayesian inference (BI) analyses were conducted in BEAST ver. 2.6.3 (Bouckaert et al. 2019), using the same partitions and equivalent models as in the ML analyses, and a chain length of 50 million generations. Every $1000^{\text {th }}$ tree was sampled, and the first $50 \%$ of trees were discarded as burn-in. Posterior probability branch support was calculated using Tree Annotator (part of the BEAST package), with values of $>0.9$ regarded as strongly supported. Trees were visualised using FigTree ver. 1.4.4 (http://tree.bio.ed.ac.uk/software/figtree/), and the Bayesian maximum credibility tree is shown.

\section{Range area calculations}

The updated geographic distribution of $P$. lirrangensis s. str. and P. kisangani sp. nov. (Fig. 1), P. amosae sp. nov. (Fig. 3), and P. orbitospinus (Fig. 2) are provided, and the extent of occurrence (EOO) for each species was calculated using GeoCAT (Bachman et al. 2011) as the area contained within the minimum convex polygon around all sites of present occurrence. The area within the EOO that is actually occupied by the taxon (the area of occupancy; AOO) was estimated using GeoCAT as the sum of the area occupied within a $2 \times 2 \mathrm{~km}$ grid overlaid around each locality.

\section{Abbreviations of museums and institutions}

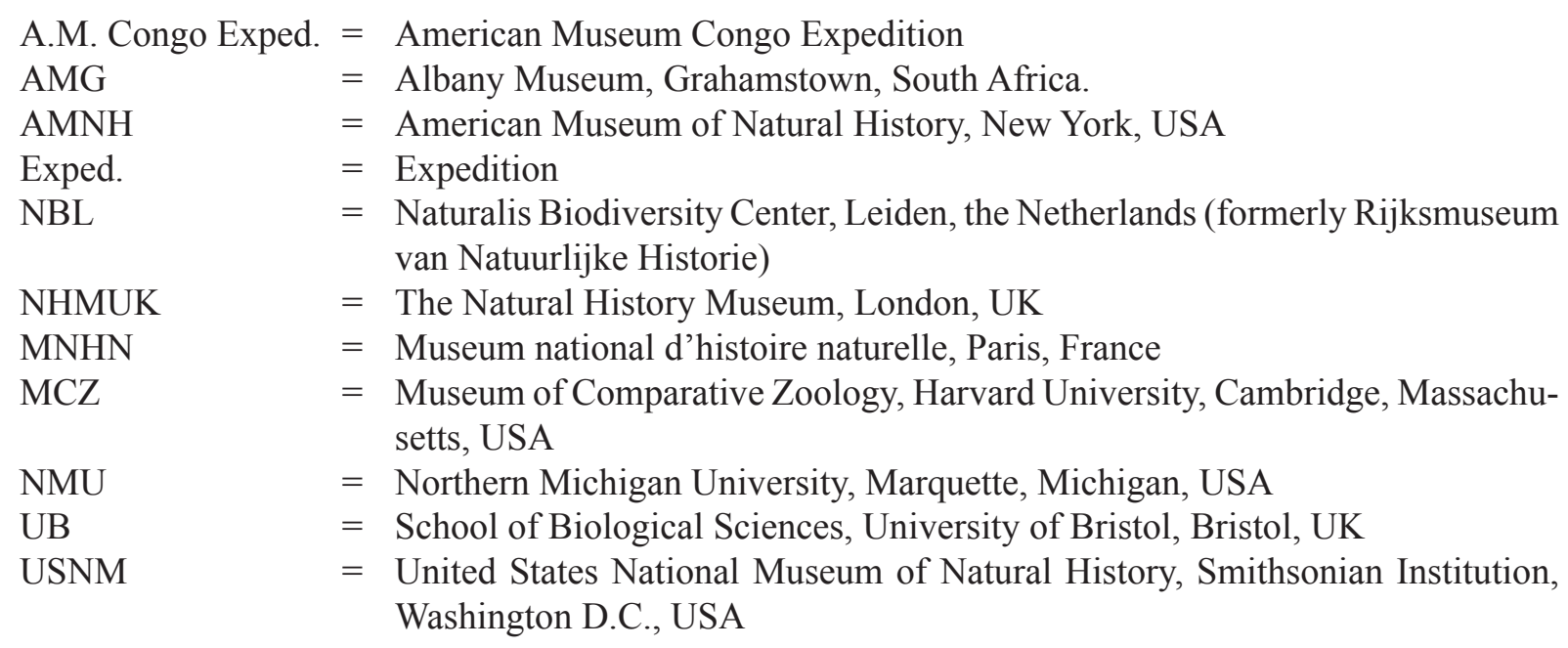

\section{Abbreviations}

$\begin{array}{ll}\mathrm{A} & =\text { pleomere (abdominal somite) } \\ \mathrm{A} 5 / 6 & =\text { sutures between pleomeres } \\ \mathrm{CH} & =\text { carapace height measured at maximum height of cephalothorax } \\ \mathrm{CL} & =\text { carapace length measured along median line from anterior to posterior margin } \\ \mathrm{CW} & \text { carapace width measured at widest point } \\ \text { D.R. Congo } & \text { Democratic Republic of the Congo } \\ \mathrm{E} & =\text { thoracic episternite } \\ \mathrm{FW} & =\text { front width measured along anterior frontal margin between orbits } \\ \mathrm{G} 1 & =\text { first male gonopod } \\ \mathrm{G} 2 & =\text { second male gonopod } \\ \mathrm{IUCN} & =\text { International Union for the Conservation of Nature } \\ \text { juv. } & =\text { juvenile } \\ \text { ovig. } & =\text { ovigerous } \\ \mathrm{P} 2-5 & =\text { pereiopods } 2-5 \text { (first to fourth ambulatory legs) } \\ \mathrm{S} & =\text { thoracic sternite } \\ \mathrm{S} 3 / 4 & =\text { sternal sulci between adjacent thoracic sternites }\end{array}$


$\mathrm{S} 4 / \mathrm{E} 4=$ episternal sulci between adjacent thoracic sternites and episternites

$\mathrm{SA}=$ subterminal article of $\mathrm{G} 1$ or $\mathrm{G} 2$

$\mathrm{TA}=$ terminal article of $\mathrm{G} 1$ or $\mathrm{G} 2$

TS $\quad=$ terminal article of mandibular palp

\section{Results}

Phylum Arthropoda Latreille, 1829

Subphylum Crustacea Brünnich, 1772

Order Decapoda Latreille, 1802

Infraorder Brachyura Latreille, 1802

Superfamily Potamoidea Ortmann, 1896

Family Potamonautidae Bott, 1970

Subfamily Potamonautinae Bott, 1970

Genus Potamonautes MacLeay, 1838

Potamonautes lirrangensis (Rathbun, 1904) sensu stricto

Figs 1, 4A, 7A, Table 1

Potamon (Potamonautes) lirrangensis Rathbun, 1904: pl. 14 fig. 8.

Potamon (Potamonautes) lirrangensis - Rathbun 1905: 169; 1921: 413-415, pls 25, 26 figs 3, 8. Balss 1914: 404; 1929: 347-348 (partim, nec D.R. Congo: Kituri upper Lualaba, Katanga Province, Russisi River, Lake Kivu); 1936: 188-189 (partim, nec D.R. Congo: Banana, Lakes Kivu, Mweru). Potamon lirrangensis - Chace 1942: 188-189. - Capart 1954: 836, fig. 28.

Potamonautes (Lirrangopotamonautes) lirrangensis - Bott 1955: 268-269 (partim, nec Lake Kivu, Kindu, Lokandu, Kinshasa, Buta, Lubo, Lulua, Luzizi, Ruzizi Rivers, Luvungu, Lake Tanganyika (Mpala, Uvira), Lake Malawi).

Potamonautes lirrangensis - Cumberlidge 1998: 201 (partim, nec Tanzania: Tukuyu formerly NeuLangenburg). - Reed \& Cumberlidge 2006: 23 (partim, nec figs 41-51, 153-154, 177 pl. V, Malawi: Lake Malawi, nec Tanzania: Kigoma District, rivers draining into Lake Tanganyika, Taveta, Mungonya River, Uvinza, Malagarasi River). - Ng et al. 2008: 171 (partim).

\section{Diagnosis}

Based on female type from Liranga. Exorbital tooth large, spine-like; lateral margin of exorbital tooth lined by small teeth, angled outward at $45^{\circ}$ to midline of carapace, straight, neither bulging outward (convex) nor curving inward (concave); epibranchial tooth small, pointed, as large as other denticles lining anterolateral margin (Fig. 4A). Anterolateral margin posterior to epibranchial tooth curving strongly outward (Fig. 4A); postfrontal crest distinct, completely traversing carapace between epibranchial teeth; posterior surface of carapace with deep urogastric grooves; cheliped carpus inner margin with two large, subequal, forwardpointing spines (Fig. 7A); cheliped merus inner lower margin with spine-like tooth distally.

\section{Material examined}

Holotype (by original designation)

REPUBLIC OF THE CONGO • 1 \% adult (dried, CW 43.7, CL 38, FW 14.5 mm); Liranga, Middle Congo River, at the confluence of the Congo and Oubangi Rivers; 5 Sep. 1891; J. Dybowski leg.; MNHN B-3826.

\section{Description}

See Diagnosis. 
Size

Medium-sized species, adult at CW $43 \mathrm{~mm}$.

\section{Colour}

The preserved specimen from Liranga is uniformly light brown.

\section{Distribution}

The revised distributional range of $P$. lirrangensis s. str. (Fig. 1) now comprises just the Middle Congo River: Liranga (not 'Lirranga' as implied from the specific epithet) in the République du Congo. This species now excludes specimens formerly identified as P. lirrangensis s. lat. from Kisangani in the D.R. Congo (Fig. 1), rivers near Kigoma draining into Lake Tanganyika, in Tanzania, Lake Tanganyika in Zambia (Fig. 3), and Lake Malawi in Malawi (Fig. 2).

\section{Ecology}

The type locality of $P$. lirrangensis s. str. in the Middle Congo River (Liranga) lies in the Sudanic Congo-Oubangi Ecoregion (Freshwater Ecoregions Of the World (FEOW \#535) (Thieme et al. 2005; Abell et al. 2008). This is more than $1000 \mathrm{~km}$ from Kisangani where Potamonautes kisangani sp. nov. is found in the Upper Congo Rapids Ecoregion (FEOW \# 539), which indicates that the habitats of these 2 taxa are different, despite both being located in the Middle Congo River. Interestingly, these 2 taxa are separated by a third ecoregion, the Cuvette Centrale (FEOW \#537).

\section{Comparisons}

Taxonomically important characters of the male cheliped, thoracic sternum, and gonopods, and the colour when alive, together with DNA data for $P$. lirrangensis s. str. will not be available until topotypal material is collected that includes an adult male. The carapace of the female type specimen from Liranga was illustrated by Capart (1954: fig. 28) and photographed by Rathbun (1904: pl. 14 fig. 8) and (together with the cheliped carpus) have been included in the present study (Figs 4A, 7A).

The lateral margin of the exorbital tooth of P. lirrangensis s. str. from Liranga (Fig. 4A) is similar to that of $P$. kisangani sp. nov. from Kisangani (Fig. 4B; Rathbun 1904: fig. 8a) and is angled outward at $45^{\circ}$ to the midline of the carapace and is straight and neither bulges outward (convex) nor curves inward (concave). This contrasts with that of P. amosae sp. nov. from Lake Kivu (Fig. 4C) and the Malagarasi River (Reed \& Cumberlidge 2006: pl. 5a), where the lateral margin of the exorbital tooth is not straight and bulges distinctly outward (convex) before meeting the postfrontal crest. This also contrasts with P. orbitospinus from Lake Malawi (Fig. 4E) where the lateral margin of the exorbital tooth curves inward (concave) and is neither straight nor convex.

The identifications of specimens as $P$. lirrangensis s. lat. by a number of authors (Rathbun 1921; Chace 1942; Bott, 1955; Reed \& Cumberlidge 2006; Cumberlidge \& Meyer 2011) are all now considered unreliable because they conflate characters from the 4 taxa that comprise the species complex under study here. Specifically, the descriptions of the male characters of $P$. lirrangensis s. lat. by the above authors combined characters from specimens from Kisangani, Lake Kivu, Tanzania, and Lake Malawi (Table 1).

Three taxonomic consequences of the treatment of $P$. lirrangensis s. lat. by Bott (1955) are addressed here. For example, that Bott (1) established the subgenus Potamonautes (Lirrangopotamonautes) Bott, 1955 with Potamon (Potamonautes) lirrangensis from Liranga, Middle Congo River as the type species; (2) included 3 taxa in this subgenus: Potamonautes (Lirrangopotamonautes) lirrangensis, $P$. $(L)$.$j .$ johnstoni (Miers, 1885) and P. (L.) johnstoni platycentron Hilgendorf, 1897; and (3) treated Potamon (Potamonautes) orbitospinus as a junior synonym of $P$. (L.) lirrangensis. The subgenus Potamonautes 


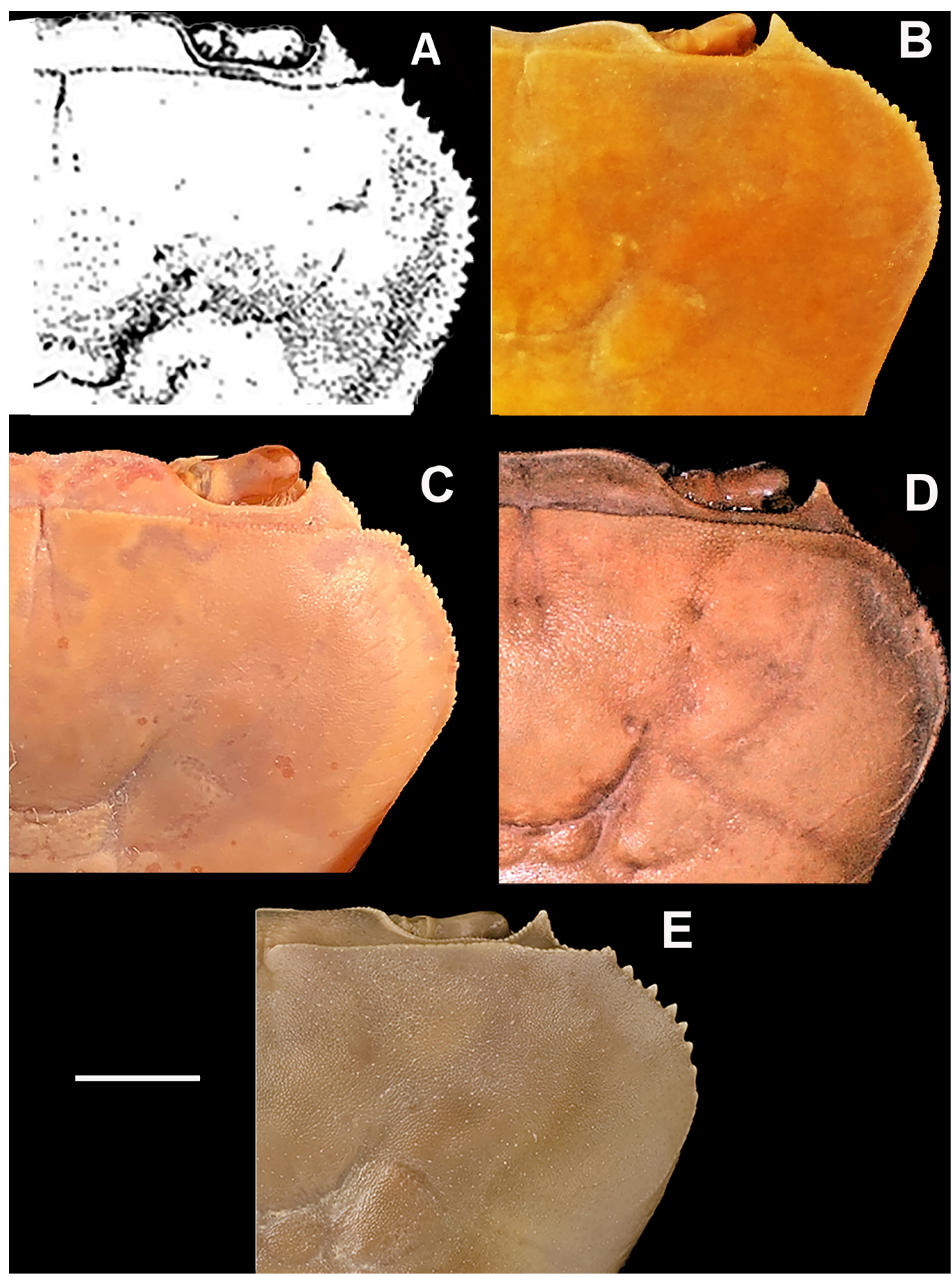

Fig. 4. Dorsal view of the right side of the carapace. A. Potamonautes lirrangensis s. str., holotype, adult, ㅇ, CW 53.6 mm, from Liranga, République du Congo (MNHN B-3826) (Capart 1954: fig. 28). B. P. kisangani sp. nov., holotype, adult, ô, CW $60.5 \mathrm{~mm}$, from Kisangani, Democratic Republic of the Congo (USNM 98944). C. P. amosae sp. nov., holotype, adult, Ô, CW $46.5 \mathrm{~mm}$, from Lake Kivu, D.R. Congo (NHMUK 2018.306). D. P. amosae sp. nov., adult, đ̂, CW 39.5 mm, from Kigoma District near Lake Tanganyika, Tanzania (NMU TRW 1971.05). E. P. orbitospinus (Cunnington, 1907), lectotype, adult, ô, CW $56.9 \mathrm{~mm}$, from Nkhata Bay, Lake Malawi, Malawi (NHMUK 1908.1.31.27). Scale bar: $A=8.7 \mathrm{~mm} ; \mathrm{B}=7.9 \mathrm{~mm} ; \mathrm{C}=6.8 \mathrm{~mm}$; $=5.7 \mathrm{~mm} ; \mathrm{E}=7.9 \mathrm{~mm}$. Photograph E by Phillip Crabb, NHMUK. 
(Lirrangopotamonautes) Bott, 1955, however, has not been recognized by subsequent authors due to doubts about the monophyly of a group comprising these 3 taxa (Reed \& Cumberlidge 2006; Ng et al. 2008). Currently, P. johnstoni (Reed \& Cumberlidge 2006: 21-23, figs 31-40, 151-152, 176 pl. IV) and P. platycentron (Reed \& Cumberlidge 2006: 30-31, figs 82-92, 161-162, 181 pl. IX) are each recognized as valid species, while the taxonomic status of $P$. orbitospinus is addressed in the present study.

\section{Conservation status}

The current IUCN extinction risk assessment of LC for P. lirrangensis s. lat. was based on the extremely wide range of that taxon (Cumberlidge 2018). The present work reduces the range of $P$. lirrangensis s. str. significantly (Fig. 1), from an estimated extent of occurrence (EOO) of almost 1.5 million $\mathrm{km}^{2}$ based on 58 localities, to a single locality that precludes the calculation of the EOO. This change will no doubt impact the conservation assessment of this species when it is revised.

Potamonautes kisangani sp. nov. urn:1sid:zoobank.org:act:77F6D732-392A-4B60-AA4A-AA2104D12C01

Figs $1,4 \mathrm{~B}, 5 \mathrm{~A}, 6 \mathrm{~A}-\mathrm{B}, 7 \mathrm{~B}, 8,11 \mathrm{~A}$, Table 1

Potamon (Potamonautes) lirrangensis - Rathbun 1921: 413-415, pls 25-26, figs 3, 8.

\section{Diagnosis}

Exorbital tooth large, spine-like; lateral margin of exorbital tooth lined by small teeth, angled outward at $45^{\circ}$ to midline of carapace, straight, neither bulging outward (convex) nor curving inward (concave); epibranchial tooth small, granular, followed by large granules lining anterolateral margin (Fig. 4B); anterolateral margin posterior to epibranchial tooth curving strongly outward (Fig. 4B); postfrontal crest distinct, completely traversing carapace between epibranchial teeth; posterior surface of carapace with deep urogastric grooves (Fig. 4B). Male thoracic sternal sulcus S3/4 deep, distinct, V-shaped. Ischium of third maxilliped with thin but distinct vertical sulcus. Major chela with 3 large molars at proximal end of both fingers (Fig. 6A-B); major chela dactylus (moveable finger) and fixed finger (pollex of propodus) both elongated, straight, slender (Fig. 6A-B); cheliped carpus inner margin with 2 large, subequal, forward-pointing spines (Fig. 7B); cheliped merus inner lower margin with spine-like tooth distally. P5 carpus, propodus, and dactylus all shortened (Fig. 8A-B). G1 TA conspicuously widened by high, rounded dorsal lobe (as wide as TA width at TA-SA junction); G1 TA distal third straight, ending in pointed tip (Fig. 11A). G1 SA at junction with G1 TA with horizontal margin on ventral side, U-shaped indentation filled by conspicuous dorsal membrane on dorsal side.

\section{Etymology}

The new species is named for Kisangani, D.R. Congo, the locality where it was first collected. The specific epithet is used as a Latin noun in apposition. The vernacular name is the Kisangani freshwater crab.

\section{Material examined}

Holotype

DEMOCRATIC REPUBLIC OF THE CONGO • $\widehat{\jmath}$ adult (CW $60.5 \mathrm{~mm}$ ); Kisangani, vicinity of Wagenia fishery; 25 Apr. 1955; Smithsonian-Bredin Congo Exped., W.L. Schmitt leg.; USNM 98944.

\section{Paratypes}

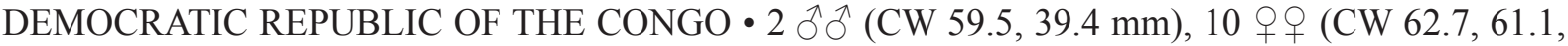
$59.2,56.9,56.8,56,51.6,48.3,44.5,40.3 \mathrm{~mm}$ ), 3 우 우 ovig. (CW 66.5, 62.8, $54.7 \mathrm{~mm}$ ); same collection data as for holotype; USNM 98944. 

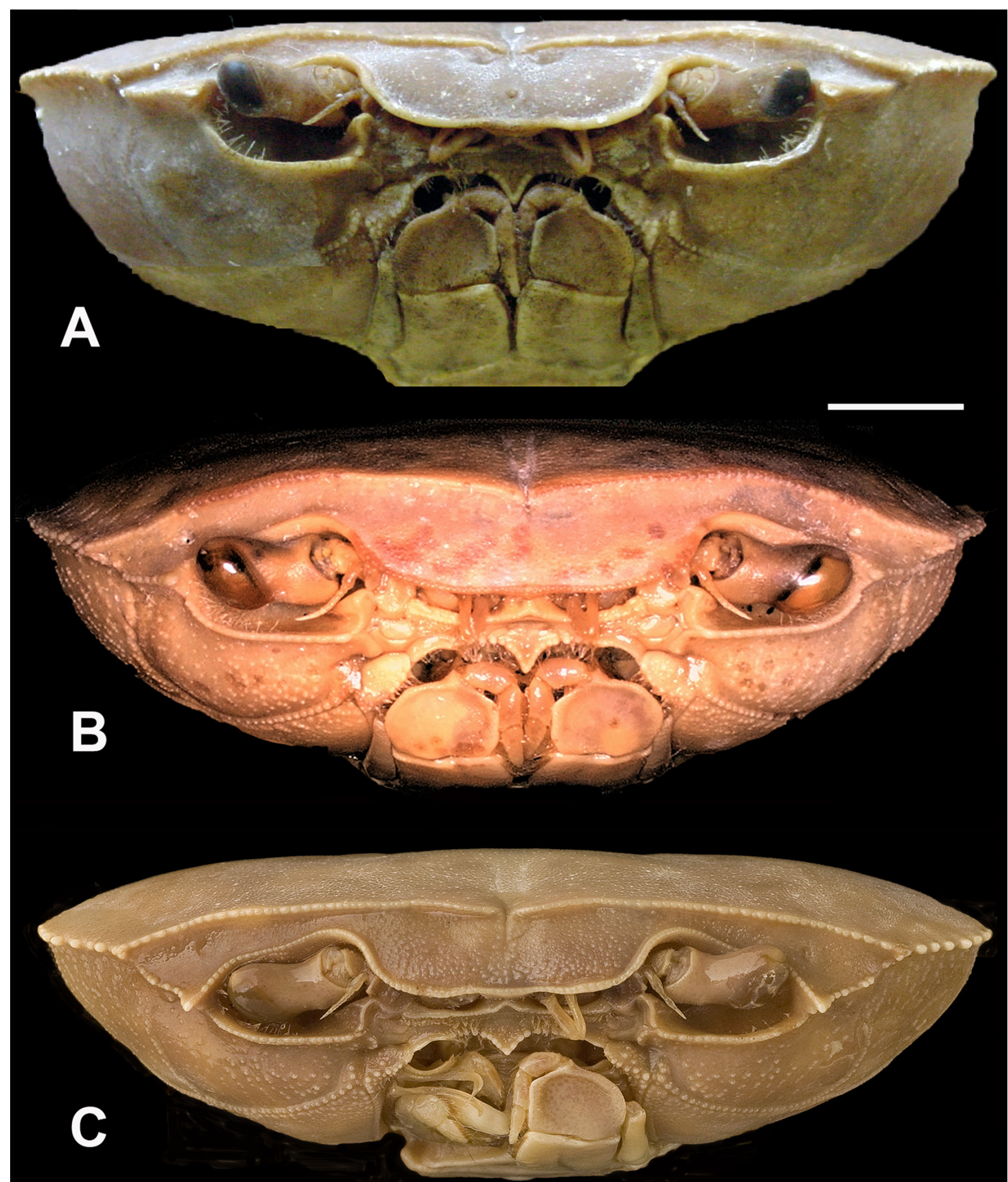

Fig. 5. Frontal view of carapace. A. Potamonautes kisangani sp. nov., holotype, adult, đ̂, CW $60.5 \mathrm{~mm}$, from Kisangani, Democratic Republic of the Congo (USNM 98944). B. P. amosae sp. nov., holotype, adult, ô, CW $46.5 \mathrm{~mm}$, from Lake Kivu, D.R. Congo (NHMUK 2018.306). C. P. orbitospinus (Cunnington, 1907), lectotype, adult, ô, CW $56.9 \mathrm{~mm}$, from Nkhata Bay, Lake Malawi, Malawi (NHMUK 1908.1.31.27). Scale bar: A $=8.5 \mathrm{~mm} ; \mathrm{B}=6.3 \mathrm{~mm}$; $=7.8 \mathrm{~mm}$. Photograph C by Phillip Crabb, NHMUK. 


\section{Other material}

DEMOCRATIC REPUBLIC OF THE CONGO • $1 \hat{\jmath}, 1$ 1 , 1 q ovig.; Kisangani; Feb. 1915; A.M. Congo Exped., H. Lang leg.; USNM 54305 • 3 우 (CW 59.8, 54.9, $45.1 \mathrm{~mm}$ ), 1 ㅇ ovig. (CW $54.8 \mathrm{~mm}$ ); same collection data as for preceding; Apr. 1915; USNM 54306 • 5 우 (CW 51.9, 49, 48.9, 45.6, $36.8 \mathrm{~mm}$ ),

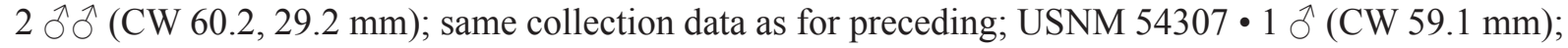
Kisangani, vicinity of Wagenia fishery; W.L. Schmitt Bredin Exped. leg.; USNM 98939 - 3 우 (CW 40.4, 40, $24.8 \mathrm{~mm}$ ); rocky gorge of Tshope Falls, Kisangani; 19 Apr. 1955; Smithsonian-Bredin Congo Exped., W.L. Schmitt leg.; USNM 98940 • 1 q (CW 53.6 mm), 3 juvs; Kisangani, vicinity of Wagenia fishery; Smithsonian-Bredin Congo Exped., W.L. Schmitt leg.; USNM 98941 - 2 우 ovig. (CW 56.5, $53.7 \mathrm{~mm}$ ), 1 + (CW $62.6 \mathrm{~mm}$ ); Kisangani; 20 Apr. 1955; Smithsonian-Bredin Congo Exped., W.L. Schmitt leg.; USNM 98942 • 1 क (with hatchlings, CW $60.1 \mathrm{~mm}$ ); Kisangani; 20 Apr. 1955; Smithsonian-Bredin Congo Exped., W.L. Schmitt leg.; USNM 98943 • 1 o (subadult CW $47.2 \mathrm{~mm}$ ); Kisangani; 22 Jun. 1955; G. Browne leg.; NHMUK 1955.6.22.65 • 1 ðૈ, 1 क; Kisangani; Apr. 1915; A.M. Congo Exped., H. Lang leg.; MCZ CRU-10613.

\section{Description}

See Diagnosis.

\section{Size}

Large-sized species, adult at CW $53 \mathrm{~mm}$, largest known specimen CW $66 \mathrm{~mm}$.

\section{Colour}

The colour of living specimens from Kisangani D.R. Congo was provided by Rathbun (1921: 415). The dorsal carapace is either dark blue, dark green, or dark brown, the thoracic sternum is pink with blue/ gray tones, and the pleon is yellow/white. The fixed and movable fingers of the chelae are dark brown/ black in recently preserved specimens (Fig. 6A-B), while the arthrodial membranes of the chelipeds are vermillion (vivid red/orange).

\section{Distribution}

This species is only known from the vicinity of Kisangani in the D.R. Congo (Fig. 1).

\section{Ecology}

Kisangani lies in the Upper Congo Rapids Ecoregion (FEOW \#539) (Thieme et al. 2005; Abell et al. 2008). The field notes of Herbert Lang on the habitat of $P$. kisangani sp. nov. from Kisangani provided by Rathbun (1921: 415) indicate that although this species is found in large rivers, it favours shallow waters near river banks where drifting logs jam. At the Boyoma Falls near Kisangani these crabs were common above and below the cataracts, while in the Tshopo River crabs were abundant among the rocks and boulder fields above the Tshopo Falls, but were absent below the falls where the water was shallow and had a sandy substrate.

\section{Remarks}

This new species was recognized to accommodate a large number of specimens from Kisangani, D.R. Congo that were collected by two U.S. Expeditions: the American Museum Congo Expedition (1909-1915) led by Herbert O. Lang and James P. Chapin, and the Smithsonian-Bredin Expedition to the Belgian Congo, Sudan, Uganda, and Egypt (1955) led by Waldo L. Schmitt. The first U.S. expedition initially deposited a large number of specimens (in 10 samples) in the AMNH and subsequently gifted some of these (USNM 54305, 54306, 54307 and MCZ CRU-10613) to these other museums. All of the specimens from the first U.S. Congo expedition were attributed by Rathbun (1921) to P. lirrangensis s. lat., and she provided a description, photographs, and illustrations of this species (Rathbun 1921: 

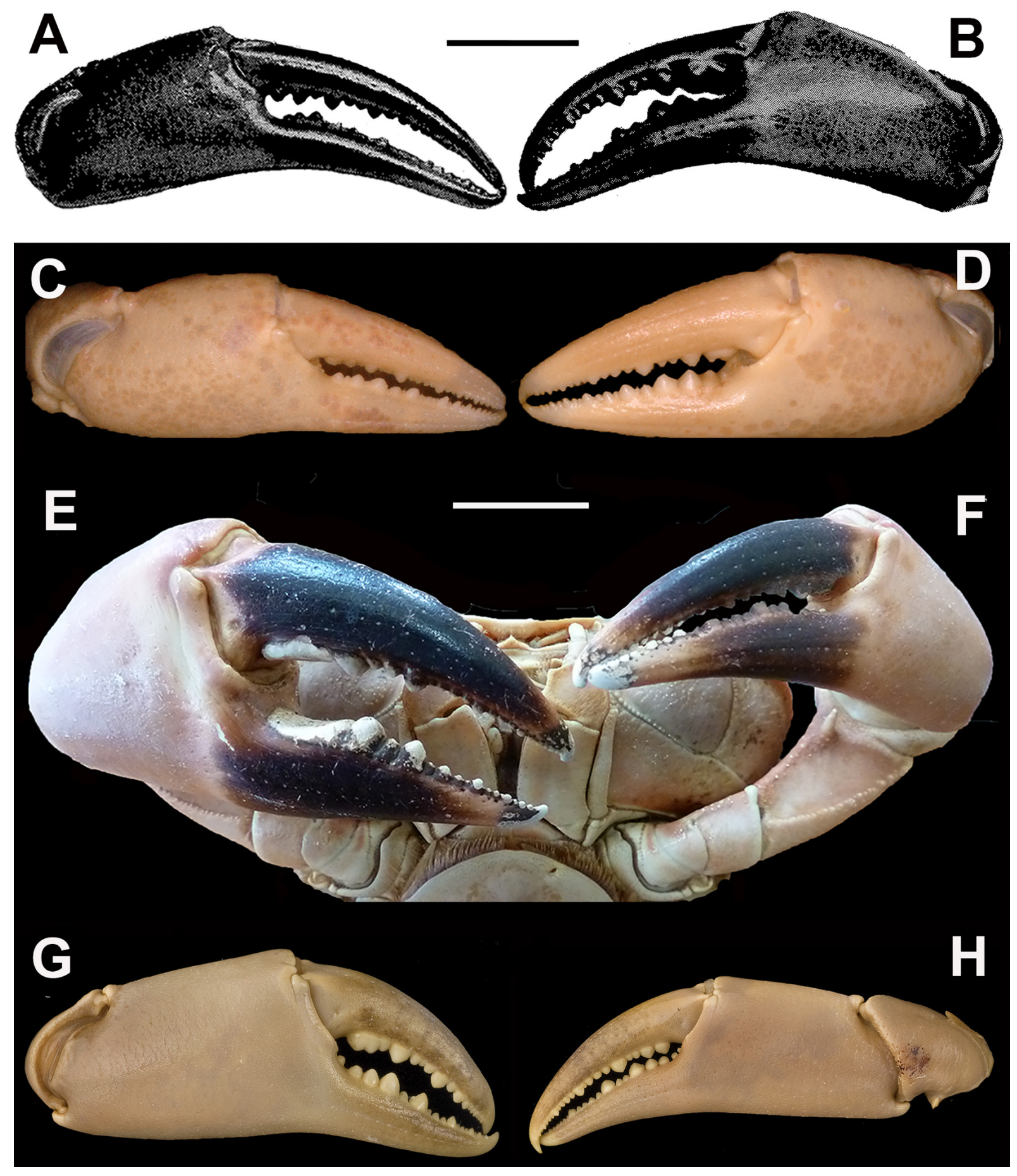

Fig. 6. Outer view of left and right chelae. A-B. Potamonautes kisangani sp. nov., holotype, adult, $\widehat{O}$, CW $60.5 \mathrm{~mm}$, from Kisangani, Democratic Republic of the Congo (USNM 98944). C-D. P. amosae sp. nov., holotype, adult, ô, CW $46.5 \mathrm{~mm}$, from Lake Kivu, D.R. Congo (NHMUK 2018.306). E-F. P. amosae sp. nov., adult, + , CW $80.1 \mathrm{~mm}$, from the Malagarasi River, Tanzania (NMU TRW 1971.05). G-H. P. orbitospinus (Cunnington, 1907), lectotype, adult, ô, CW $56.9 \mathrm{~mm}$, from Nkhata Bay, Lake Malawi, Malawi (NHMUK 1908.1.31.27). Scale bars: A-B $=10.9 \mathrm{~mm}$; C-D $=8.9 \mathrm{~mm}$; E-F $=11.0 \mathrm{~mm} ; \mathrm{G}-\mathrm{H}=8.9 \mathrm{~mm}$. Photographs $\mathrm{G}-\mathrm{H}$ by Phillip Crabb, NHMUK. 


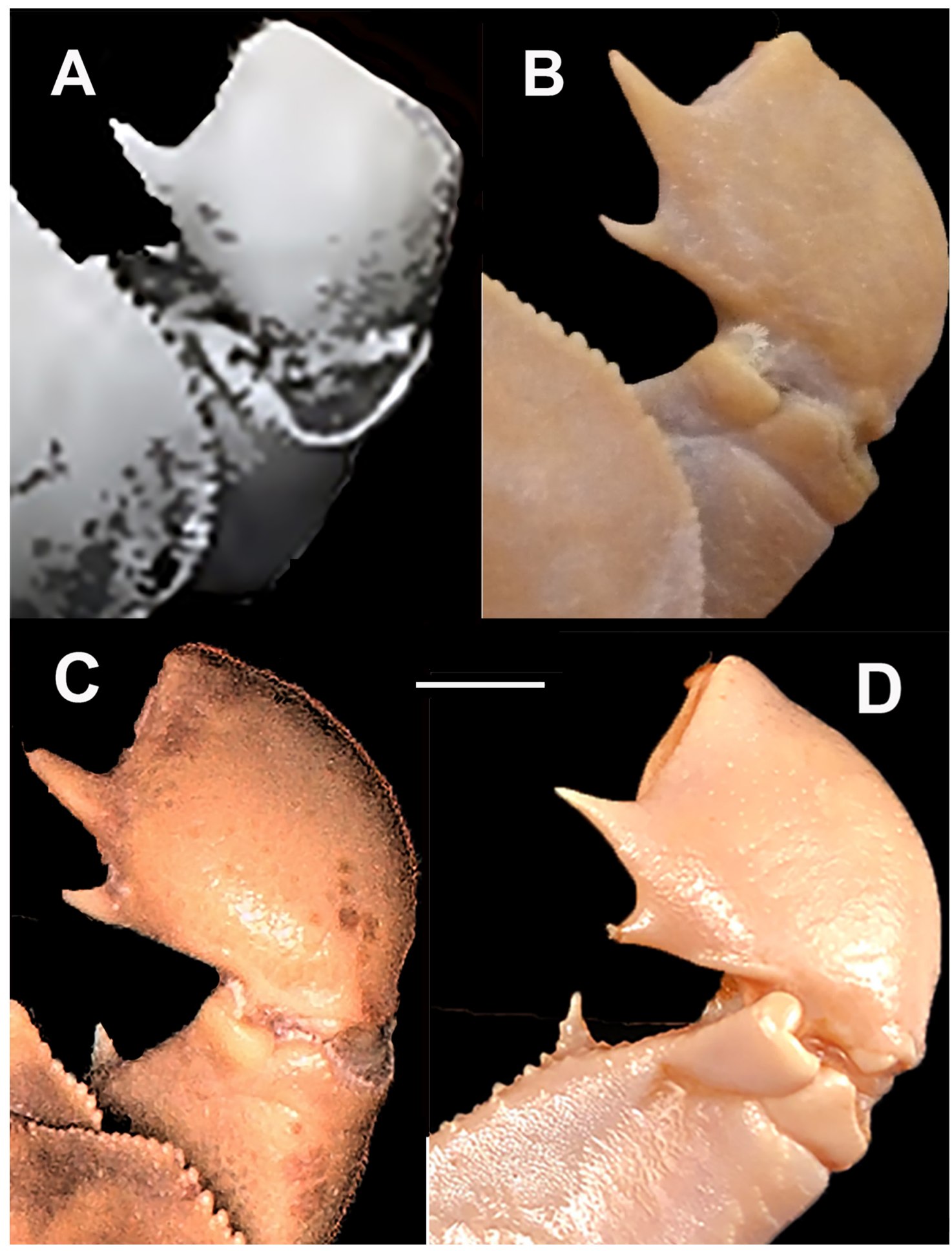

Fig. 7. Dorsal view of right cheliped carpus. A. Potamonautes lirrangensis s. str., holotype, adult,, , CW 53.6 mm, from Liranga, République du Congo (MNHN B-3826) (Rathbun, 1904: pl. 14, fig. 8). B. P. kisangani sp. nov., holotype, adult, ô, CW $60.5 \mathrm{~mm}$, from Kisangani, Democratic Republic of the Congo (USNM 98944). C. P. amosae sp. nov., holotype, adult, ô, CW $46.5 \mathrm{~mm}$, from Lake Kivu, D.R. Congo (NHMUK 2018.306). D. P. orbitospinus (Cunnington, 1907), lectotype, adult, ठૈ, CW $56.9 \mathrm{~mm}$, from Nkhata Bay, Lake Malawi, Malawi (NHMUK 1908.1.31.27). Scale bar: A=5.7 mm; $\mathrm{B}=4.8 \mathrm{~mm} ; \mathrm{C}=3.6 \mathrm{~mm} ; \mathrm{D}=4.9 \mathrm{~mm}$. Photograph D by Phillip Crabb, NHMUK. 
413-415, pls 25-26, figs 3, 8). The second U.S. Congo expedition in 1955 also collected a number of specimens (in 7 samples) from Kisangani (examined in the present work) that were also initially attributed to $P$. lirrangensis s. lat. Figures of the carapace, chelipeds, and $\mathrm{G} 1$ of the adult male holotype from Kisangani, D.R. Congo (Figs 4B, 5A, 6A-B, 7B, 8A-B, 11A) are provided for comparison with

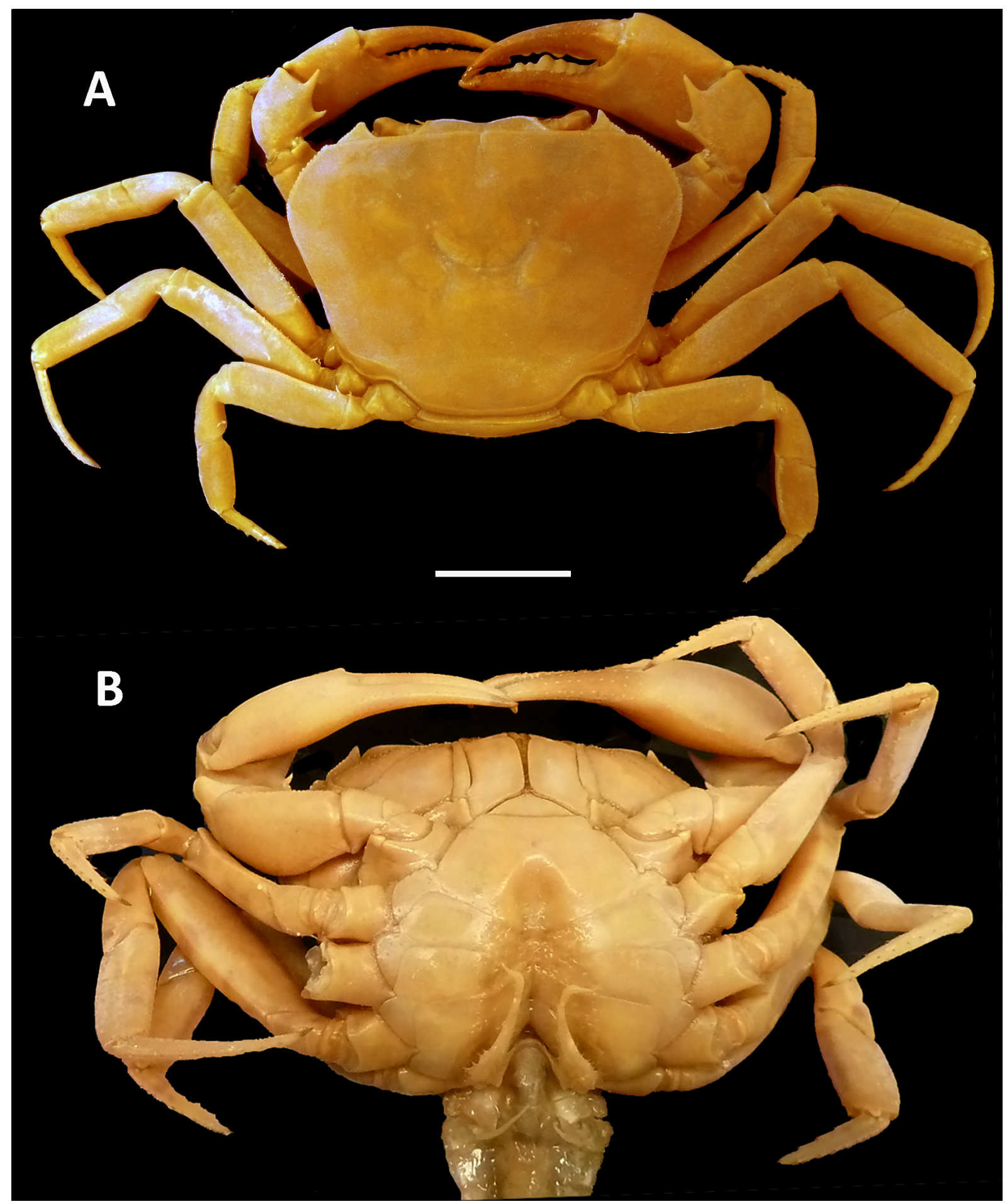

Fig. 8. Potamonautes kisangani sp. nov. A. Adult,, , whole animal, dorsal view. B. Adult, $\widehat{\jmath}$, whole animal, ventral view. Scale bar $=10 \mathrm{~mm}$. 
the other taxa included here. One character that distinguishes this species from $P$. lirrangensis $\mathrm{s}$. str. is the epibranchial tooth, which is small and granular, followed by large granules lining the anterolateral margin in P. kisangani sp. nov. (Fig. 4 B) (vs pointed and as large as the other teeth lining the anterolateral margin in P. lirrangensis s. str. from Liranga; Fig. 4A). The absence of DNA sequence data for any of the specimens from Kisangani means that it is not possible to test the monophyly of $P$. kisangani sp. nov. using molecular data.

\section{Comparisons}

The epibranchial tooth and anterolateral margin of P. kisangani sp. nov. from Kisangani (Fig. 4B) and of P. amosae sp. nov. from Lake Kivu (Fig. 4C) and the Malagarasi River (Fig. 4D; Reed \& Cumberlidge 2006: pl. 5a) are similar in both species: the epibranchial tooth is a small granule that is followed by large granules lining the anterolateral margin. In contrast, the epibranchial tooth of $P$. lirrangensis s. str. from Liranga (Fig. 4A) and of P. orbitospinus from Lake Malawi (Fig. 4E) is pointed and as large as the other teeth lining the anterolateral margin.

The male thoracic sternal sulcus S3/4 of P. kisangani sp. nov. from Kisangani (Fig. 8B) and of P. orbitospinus from Lake Malawi (Fig. 10B) is deep, distinct, and V-shaped, whereas this sulcus is faint in P. amosae sp. nov. from Lake Kivu (Fig. 9B) and the Malagarasi River (Reed \& Cumberlidge 2006: pl. 5c).

The ischium of the third maxilliped of P. kisangani sp. nov. from Kisangani (Fig. 5A) and of P. orbitospinus from Lake Malawi (Fig. 5C) has a thin but distinct vertical sulcus, whereas this sulcus is faint and obscure in P. amosae sp. nov. from Lake Kivu (Fig. 5B) and the Malagarasi River (Reed \& Cumberlidge 2006: pl. 5c-d).

The chela dactylus (moveable finger) and fixed finger (pollex of propodus) of $P$. kisangani sp. nov. from Kisangani (Fig. 6A-B) are both elongated and slender, whereas the chela fingers in P. amosae sp. nov. from Lake Kivu (Fig. 6C-D) and from the Malagarasi River (Fig. 6E-F; Reed \& Cumberlidge 2006: pl. 5a figs 46-47; NMU TRW1972.04), and in P. orbitospinus from Lake Malawi (Fig. 6G-H), are thick and broad.

The major chela has 3 large molars at the proximal ends of both fingers, with older specimens showing fusion of these teeth into a flat surface of the fixed finger in P. kisangani sp. nov. from Kisangani (Figs 6A-B, 8A) and in P. amosae sp. nov. from the Malagarasi River (CW $80.1 \mathrm{~mm}$ ) (Fig. 6E-F; Reed \& Cumberlidge 2006: pl. 5a figs 46-47), whereas the proximal parts of both fingers of the major chela in P. orbitospinus from Lake Malawi (Fig. 6G-H) has enlarged, rounded, separate (unfused) teeth.

The P5 carpus, propodus, and dactylus of $P$. orbitospinus from Lake Malawi (Figs 10B, 13) are all elongated and slender, whereas these ambulatory leg articles in $P$. kisangani sp. nov. from Kisangani (Fig. 8A-B) and of P. amosae sp. nov. from Lake Kivu (Fig. 9A-B) and the Malagarasi River (Reed \& Cumberlidge 2006: pl. 5a) are all short and stocky.

The G1 TA in P. kisangani sp. nov. from Kisangani (Fig. 11A) and P. amosae sp. nov. from Lake Kivu (Fig. 11B-D, F) and the Malagarasi River (Reed \& Cumberlidge 2006: pl. 5c-d fig. 152) is only slightly widened by a low dorsal lobe and the TA ends in either a straight, or only slightly upcurved tip. This contrasts with the G1 TA in P. orbitospinus from Lake Malawi, which is conspicuously widened by a high, rounded dorsal lobe (as wide as the TA width at the TA-SA junction) and the G1 TA ends in a strongly curved upwards tip (Fig. 12A-H). 


\section{Potamonautes amosae sp. nov. urn:lsid:zoobank.org:act:1B3001B9-7101-4551-AE46-2BEFCAD3598A}

Figs 3, 4C-D, 5B, 6C-F, 7C, 9, 11B-F, 14, Table 1

Potamon (Potamonautes) lirrangensis - Balss 1936: 188 (partim, nec 189, fig. 24, Lirranga, Stanleyville; Kituri uberer Lualaba. Katanga-region). - Chace 1942: 188-189, fig. 1. - Capart 1952: 62-64, figs $12,14 \mathrm{c}-\mathrm{d}$.

Potamonautes (Lirrangopotamonautes) lirrangensis - Bott 1955: 268-270, pl. XVI figs 2a-d, 38-39, 83. - Coulter 1991: 253, 255, tabs 9.XX, 9.XXI.

Potamonautes lirrangensis - Cumberlidge 1998: 201. — Reed \& Cumberlidge 2006: figs 41-51, 153 154, 177 pl. V (partim). — Cumberlidge \& Meyer 2011: 1845-1848 (partim, nec Malawi: Lake Malawi).

\section{Diagnosis}

Exorbital tooth large forward-pointing spine; lateral margin of exorbital tooth lined by granules before meeting postfrontal crest; epibranchial tooth small, granular, followed by small granules lining anterolateral margin (Fig. 4C-D). Anterolateral margin posterior to epibranchial tooth curving strongly outward (Fig. 4C-D); postfrontal crest distinct, completely traversing carapace between epibranchial teeth; posterior surface of carapace with deep urogastric grooves; third maxilliped ischium smooth (either lacking vertical sulcus or with faint sulcus); thoracic sternal sulcus S3/4 faint, shallow (Fig. 9B); major chela fixed finger with 3 large molars proximally, fused in older specimens into flat surface (Figs 6A-B, 8A); cheliped carpus inner margin with two large, subequal, forward-pointing spines (Fig. 7C); cheliped merus inner lower margin with spine-like tooth distally; $\mathrm{P} 5$ carpus, propodus, and dactylus not elongated (Fig. 9A-B); G1 TA (Fig. 11C-F) slightly widened by slim dorsal lobe (1/3 TA width at TA-SA junction); tip straight, only slightly curved upwards.

\section{Etymology}

The new species is named to honour the memory of Marilyn Suzanne Amos, of Mobile, Alabama, USA, who passed away during these studies. She was the mother of the second author (EJ). The specific epithet is used as a Latin noun in apposition. The vernacular name is Amos's crab.

\section{Material examined}

Holotype

DEMOCRATIC REPUBLIC OF THE CONGO - ô subadult; Idjwi Island, Lake Kivu; $2.082854^{\circ} \mathrm{S}$, 29.071167 E; Feb. 1939; A. Loveridge leg.; MCZ CRU-11224.

\section{Other material}

DEMOCRATIC REPUBLIC OF THE CONGO • 1 त subadult (CW $46.5 \mathrm{~mm}$ ); Lake Kivu; donated by Royal Belgian Institute of Natural Sciences, Brussels; NHMUK 2020.3 • 1 त subadult (CW $44.5 \mathrm{~mm}$ ); Goma, Lake Kivu; 30 Nov. 1952; I. Gordon leg.; wide coast; NHMUK 2020.4.

RWANDA • 1 § juv. (CW 30.0, CL 23.7, CH 11.2, FW 9.8 mm); Gisenye, Lake Kivu; Mar. 1936; J.C. Bequaert leg.; MCZ CRU-9177 • 1 q juv. (CW 26.9 mm); Gisenye, Lake Kivu; 12 May 1955; Smithsonian-Bredin Congo Exped., W.L. Schmitt leg.; in water at shoreline; USNM 98937 • 1 o adult (CW 62 mm); Kalemie (formerly Albertville), Lake Tanganyika; 8 Mar. 1919; M. Dhont de Bie leg.; NHMUK 1919.3.8.1-3.

TANZANIA • 1 ô subadult (CW $39.5 \mathrm{~mm}$ ); Mungonya River, Mwandiga, near Kigoma; $4.828819^{\circ} \mathrm{S}$, 29.666191 ${ }^{\circ}$ E; Apr. 1971; T.R. Williams leg.; NMU TRW 1971.05 1 q adult (CW 80.1 mm); Malagarasi River, Uvinza, Kigoma District; $5.115673^{\circ}$ S, $30.380144^{\circ}$ E; Apr. 1971; T.R. Williams leg.; NMU TRW 1971.15. 


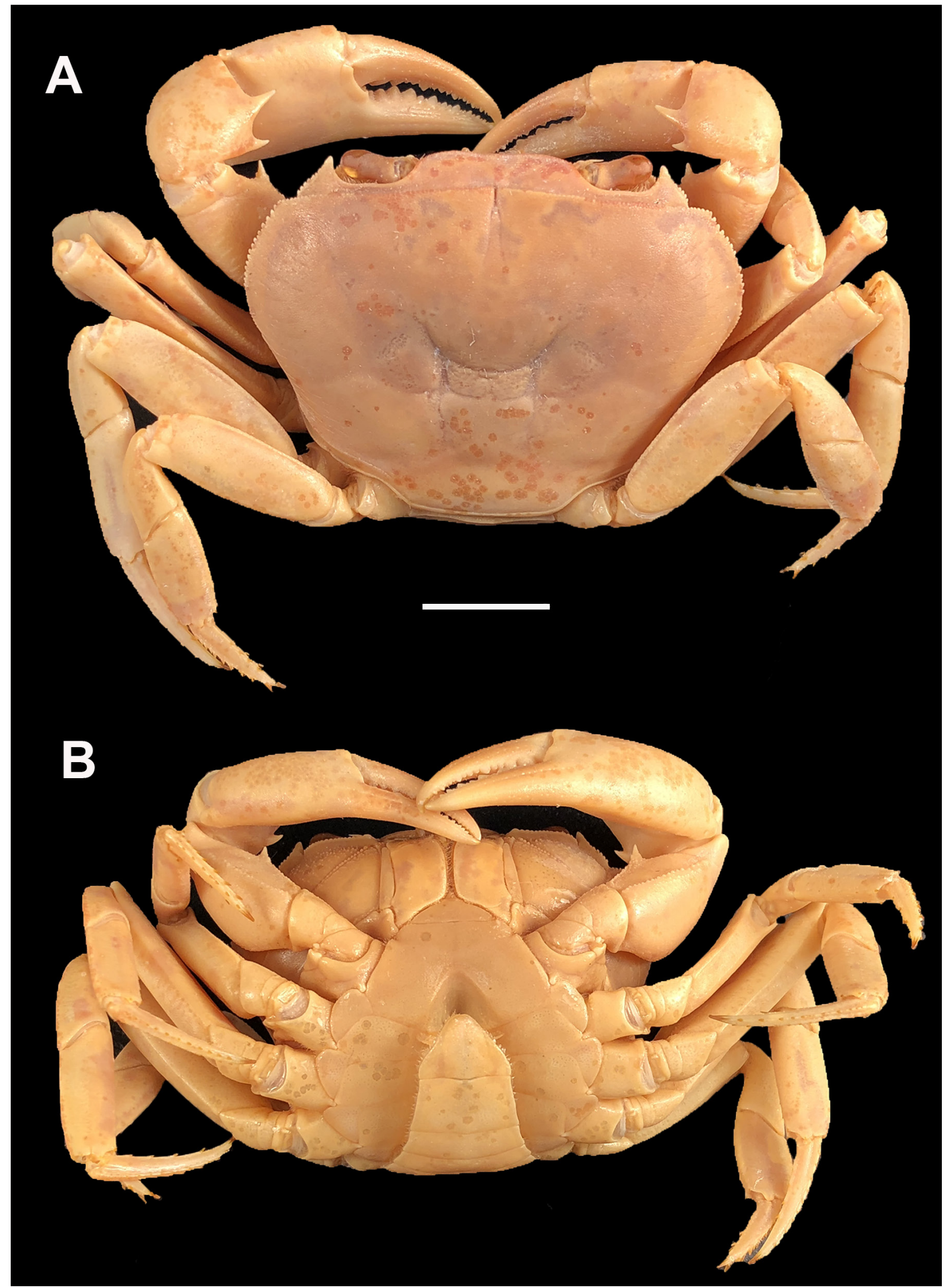

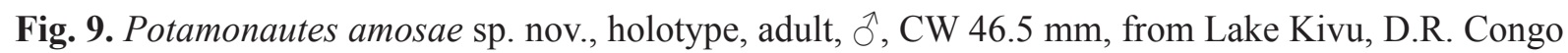
(NHMUK 2018.306). A. Entire animal, dorsal view. B. Entire animal, ventral view. Scale bar $=11.3 \mathrm{~mm}$. 


\section{Description}

Carapace height equal to front width $(\mathrm{CH} / \mathrm{FW} \mathrm{1.0)}$; carapace length $2.4 \times$ front width $(\mathrm{CL} / \mathrm{FW} 2.5)$; carapace width $\sim 3 \times$ front width (CW/FW 3.1); posterior region of carapace with deep urogastric grooves; exorbital tooth large forward-pointing spine; lateral margin of exorbital tooth lined by small granules; epibranchial tooth small, granular, followed by large granules lining anterolateral margin (Fig. 4C-D); anterolateral margin posterior to epibranchial tooth curving strongly outward (Fig. 4C-D); postfrontal crest distinct, completely traversing carapace between epibranchial teeth; posterior surface of carapace with deep urogastric grooves; carapace branchiostegal wall divided by pleural (vertical) suture into suborbital region (with granules on surface), subhepatic region (with granules, crinae on surface); divided by epimeral (longitudinal) suture; pterygostomial region with granules on surface (Fig. 5B). Epistomial tooth prominent, granulated, V-shaped. Mandible palp comprising 2 articles; terminal article single, undivided, with setae (but no hard flap) at junction between articles. Third maxillipeds filling entire oral field, except for transversely ovate respiratory openings at superior lateral corners; exopod with long flagellum; third maxilliped ischium smooth (either lacking vertical sulcus or with faint sulcus). Thoracic sternal sulcus S3/4 faint, shallow; episternal sulci S4/E4, S5/E5, S6/E6, and S7/E7 faint.

Major chela dactylus (moveable finger) and pollex of propodus (fixed finger) thick, broad, leaving long thin interspace between fingers when closed; both fingers with 3 large teeth proximally, other teeth small unfused distally; major chela fixed finger proximal molars fused into flat surface in older specimens from the Malagarasi River (CW $80.1 \mathrm{~mm}$ ) (Fig. 6E-F); cheliped carpus inner margin with two large subequal forward-pointing spines (Fig. 7C); cheliped merus lower margins heavily granulated, inner lower margin with spine-like tooth distally; P3 longest, P5 shortest (carpus, propodus, and dactylus not elongated); P2-5 dactyli tapering to pointed tip, each bearing 4 rows of downward-pointing, short, sharp spines.

Male pleon slim, triangular, telson narrow triangle with rounded apex, pleomeres Al-6 quadrate. G1 TA proximal third straight, not widened, margins parallel, at midpoint bent sharply outward at $60^{\circ}$ angle to longitudinal axis of G1 SA; G1 TA (Fig. 11B-E) widened by low dorsal lobe ( $1 / 3$ TA width at TA-SA junction); tip straight, only slightly upcurved. G1 SA at junction with G1 TA with horizontal margin on ventral side, U-shaped indentation filled by conspicuous dorsal membrane on dorsal side. G2 TA long, flagellum-like (Fig. 11F). Margins of G1 TA, SA lined by setae.

\section{Size}

Large species, adult size range between CW 50 to $80 \mathrm{~mm}$.

\section{Colour}

Preserved specimens are uniformly light brown like the holotype, but the large adult female from the Malagarasi River in Tanzania has black pigmentation on both fingers of the chelae (Fig. 6E-F).

\section{Distribution}

Potamonautes amosae sp. nov. was collected from rocky areas of Lake Kivu in the D.R. Congo and Rwanda (Fig. 3). Lake Kivu is a relatively small (100 km long by $50 \mathrm{~km}$ wide), deep lake (depth $480 \mathrm{~m}$ ) situated in the Albertine Rift of the Western Rift Valley. This lake is divided by the border between the D.R. Congo and Rwanda, with the large Idjwi Island lying in the D.R. Congo. The Ruzizi River drains south out of Lake Kivu and links it to the northern part of Lake Tanganyika in Burundi, but this species has not been recorded from this river. Potamonautes amosae sp. nov. is found along the eastern shores of Lake Tanganyika in localities associated with the Malagarasi River in western Tanzania (Capart 1952; Reed \& Cumberlidge 2006; M. Mbalassa \& S. Marijnissen pers. com.) where it flows through the Kigoma District, and on the western shores of Lake Tanganyika at Kalemie in the D.R. Congo (Capart 1952). 


\section{Ecology}

Little is known about the habitat and ecology of $P$. amosae sp. nov. In the region of Lake Tanganyika this species was often captured in marshes and wetlands near the lake, but never in the lake itself (Capart 1952). In Lake Kivu this species is found on islands in the lake as well as in the lake (Chace 1942). The range of $P$. amosae sp. nov. includes part of the Lake Victoria Basin Freshwater Ecoregion (FEOW \#521) (Thieme et al. 2005; Abell et al. 2008).

\section{Conservation status}

An IUCN extinction risk assessment of $P$. amosae sp. nov. has not yet been carried out. This species has a wide distributional range (with an estimated extent of occurrence (EOO) of almost $46600 \mathrm{~km}^{2}$ ) and has been recorded from seven localities (Fig. 3) in three different countries. Given that there are no known immediate threats to this species, it would probably be assessed as Least Concern.

\section{Remarks}

There are a number of characters that distinguish P. amosae sp. nov. from P. orbitospinus in Lake Malawi. For example, the male thoracic sternal sulcus $\mathrm{S} 3 / 4$ of $P$. amosae sp. nov. is faint and shallow (vs deep and complete in P. orbitospinus); the low dorsal lobe of the G1 TA of $P$. amosae sp. nov. means that it is only slightly widened (vs a G1 TA dorsal margin that is conspicuously widened by a high dorsal lobe in P. orbitospinus); the anterolateral margin of $P$. amosae sp. nov. is lined by small granules (vs lined by a row of small distinct teeth in $P$. orbitospinus); the merus, propodus, and dactylus of $\mathrm{P} 5$ of $P$. amosae sp. nov. are all short (vs all elongated and slender in P. orbitospinus); and the third maxilliped ischium of $P$. amosae sp. nov. is smooth (vs with a third maxilliped ischium that has a deep vertical sulcus in P. orbitospinus).

In the past, $P$. amosae sp. nov. from Lake Kivu has been identified as $P$. lirrangensis s. lat. by a number of authors (Chace 1942; Bott 1955; Reed \& Cumberlidge 2006; Cumberlidge \& Meyer 2011). These identifications were made based on characters shared with the type of $P$. lirrangensis $\mathrm{s}$. str. from Liranga (such as denticles or granules lining the anterolateral margin, 2 large pointed spines on the cheliped carpus inner margin, and a large pointed spine on the cheliped merus inner margin). There are a number of illustrations of $P$. amosae sp. nov. available, but most of these specimens have been identified as P. lirrangensis s. lat. For example, Chace (1942) illustrated the carapace and G1 of a specimen from Lake Kivu (MCZ CRU-11224), and Capart (1952: fig. 12) figured an entire specimen from Kalemie (formerly Albertville) on the western shores of Lake Tanganyika and remarked on its similarity to the species found in Lake Kivu. Later, Reed \& Cumberlidge (2006: figs 41-51, 153-154, 177 pl. V) described in detail an adult female (CW $81 \mathrm{~mm}$ ) and male (CW $56.5 \mathrm{~mm}$ ) of P. lirrangensis s. lat. (NMU TRW1971.15) from the Malagarasi River at Uvinza in the Kigoma District of Tanzania near Lake Tanganyika.

DNA sequence data are available from specimens formerly assigned to $P$. lirrangensis s. lat. from Lakes Kivu, Tanganyika, and Malawi (Marijnissen et al. 2006; Daniels et al. 2015; Kochey et al. 2017). Marijnissen et al. (2006) used 2 mitochondrial DNA sequence markers (12S rRNA and 16S rRNA) to investigate relationships between specimens identified morphologically as $P$. lirrangensis s. lat. from Ruzizi in Lake Kivu in the D.R. Congo (GenBank DQ203210, DQ203236), from Uazua in the Zambian part of Lake Tanganyika (DQ203211, DQ203237), and from Thumbi West Island near Cape Maclear in southern Lake Malawi (GenBank DQ203209, DQ203235). Marijnissen et al. (2006: fig. 1) found that the specimen from Lake Kivu (here recognised as $P$. amosae sp. nov.) formed a separate basal lineage from the clade formed by the other 2 specimens from Lake Malawi (here recognised as P. orbitospinus).

Daniels et al. (2015) sequenced four DNA markers (GenBank AY803494, AY803534, AY803568, AY803682) for a specimen (ZMA.Crust.De.204681) held in the NBL that was identified in that work as 
P. lirrangensis s. lat. and incorrectly listed as being from Lake Malawi. In fact, specimen ZMA.Crust. De.204681 was collected from Lake Kivu (site 13, E. major; 23 Aug. 2002; Pascal Isumbisa leg.) and is therefore properly identified as $P$. amosae sp. nov.

There is molecular support for the recognition of $P$. amosae sp. nov. as a valid species from mitochondrial 16S rRNA and the nuclear coding gene Histone H3 sequences (Fig. 14). Across the 2 genes, 5 specimens are assigned to P. amosae sp. nov.: 3 from Uvinza, Kigoma District, Tanzania (2016-07-08-UV1; 201607-08-UV2; 2016-07-08-UV3), and two from Lake Kivu. The first specimen from Lake Kivu is ZMA. Crust.De.204681 represented by AY803534 and AY803682 (Daniels et al. 2015); the second specimen is from Ruzizi, Lake Kivu represented by DQ203236 (Marijnissen et al. 2006).

Potamonautes orbitospinus (Cunnington, 1907)

Figs 2, 4E, 5C, 6G-H, 7D, 10, 12-14, Table 1

Potamon (Potamonautes) orbitospinus Cunnington, 1907: 259-261, pl. 16 fig 1.

Potamon (Potamonautes) orbitospinus - Balss 1929: 349 (partim, nec D.R. Congo: Lake Kivu). Potamon orbitospinus - Chace 1942: 218.

\section{Common name}

The Malawi blue crab.

\section{Diagnosis}

Exorbital tooth large forward-pointing spine; lateral margin of exorbital tooth not angled, in line with midline axis of carapace curving slightly inward (concave) before meeting postfrontal crest; epibranchial tooth pointed, as large as other teeth lining anterolateral margin (Fig. 4E). Anterolateral margin posterior to epibranchial tooth curving strongly outward (Fig. 4E); postfrontal crest distinct, completely traversing carapace between epibranchial teeth; posterior surface of carapace with deep urogastric grooves; third maxilliped ischium with thin, deep vertical sulcus; thoracic sternal sulcus S3/4 deep, V-shaped, completely traversing sternum (Fig. 10B); cheliped carpus inner margin with two large, subequal, forward-pointing spines (Fig. 7D); cheliped merus inner lower margin with spine-like tooth distally; P5 carpus, propodus, and dactylus all slender, distinctly elongated; G1 TA (Fig. 12A-C, E-G, ) conspicuously widened by high, rounded dorsal lobe (as wide as TA width at TA-SA junction); tip distinctly curved upwards.

\section{Material examined}

Lectotype (here designated)

MALAWI $\bullet$ adult (CW 56.9, CL 38.4, FW $13.8 \mathrm{~mm}$ ); western shore of Lake Malawi; 31 Jan. 1908; Tanganyika Exped., J.E.S. Moore leg.; NHMUK 1908.1.31.27.

\section{Paralectotypes}

MALAWI • 3 juvs (including CW 33.2, CL 22.8, CH 11.6, FW 10.0 mm); Lake Malawi; 19 Dec. 1891; M. Woodward leg.; NHMUK 1891.12.19.1 to NHMUK 1891.12.19.3 • 1 ô subadult (CW 27.5 mm); Universities Mission, Likoma, Lake Nyassa (now Lake Malawi); 14 Jan. 1893; J.A Williams leg.; NHMUK 1893.1.14 1 ㅇ adult (CW $52.8 \mathrm{~mm}$ ); west coast of Lake Malawi from Nkhata Bay to Ruarwe; Jun. 1896; A. Whyte leg.; NHMUK 1897.4.29.1 • several subadults; Nkhata Bay, Lake Malawi; 23 Jun. 1904; Third Tanganyika Exped., local fishermen and Dr W.A. Cunnington leg.; NHMUK 1897.4.29.23. 


\section{Additional material}

MALAWI -2 우 0 adults (CW 61.1, $65.8 \mathrm{~mm}$ ), 2 우 sobadults (CW 36.7, $45.1 \mathrm{~mm}$ ), 1 万 subadult (CW 36.6 mm), 9 juvs; Lake Malawi, N of Hudzi; 20 Oct. 1926; Cristy leg.; NHMUK 1926.10.20.1 to NHMUK 1926.10.20.5 1 त subadult (CW 31.1 mm); NW coast of Lake Malawi, near Nkhata Bay; 31 Jan. 1908; NHMUK 1908.1.31.16-18 1 ㅇ adult (CW 55.6 mm); Lake Malawi, Monkey Bay; 20 Oct. 1926; NHMUK 1926.10.20.6 1 ô subadult (CW $49 \mathrm{~mm}$ ), 1 q adult with hatchlings (CW $64.8 \mathrm{~mm}$ ); NW coast of Lake Malawi, near Nkhata Bay; 26 Jul. 1954; Miers leg.; NHMUK 1954.7.26.5, NHMUK 1954.7.26.6 1 $q$ adult (CW 61.1 mm), 1 od adult (CW 55.4 mm); Lake Malawi; 5 Jun. 1956; G. Fryer leg.; NHMUK 1956.6.5.10, NHMUK 1956.6.5.11 • 1 o adult (CW $57 \mathrm{~mm}$ ), 1 ภ subadult (CW 40 mm), 2 juvs (CW 32.5, 33.4 mm); Lake Malawi; 26 Jul. 1954; W.A. Cunnington leg.; NHMUK 1954.7.26.3, NHMUK 1954.7.26.4 • 1 o subadult (CW 51.1 mm); Lake Malawi, Monkey Bay; Mar. 1968; D.H. Eccles leg.; among rocks in sand; NMU TRW 1972.04 • 1 § subadult (CW 46.2 mm); Lake Malawi, 2 km ENE of Monkey Bay; May 1968; D.H. Eccles leg.; NMU TRW 1972.05 • 1 + subadult (CW 51.1 mm); Lake Malawi; Sep. 1988; Irv. Kornfield leg.; NMU 09.1988k.1 •1 + (damaged); Lake Malawi, N of Monkey Bay; 5 Apr. 1972; D.H. Eccles leg.; depth 91 m; NMU TRW1972.02 1 (CW 51.4 mm); Lake Malawi, Monkey Bay; 24 Mar. 1968; D.H. Eccles leg.; among rock in sand with little vegetation; NMU TRW1972.04 - 1 त (CW $46.5 \mathrm{~mm}$ ); Lake Malawi, ENE of Monkey Bay; 23 May 1968; D.H. Eccles leg.; NMU TRW1972.05 • 1 त subadult (CW 46.5 mm); Lake Malawi, Cape Maclear; M. Genner leg.; NHMUK 2010-06-CM-CM6• 1 q subadult (CW 50.15 mm); same collection data as for preceding; NHMUK 2010-06-CM-CM8 1 1 adult (CW $52.2 \mathrm{~mm}$ ); same collection data as for preceding; Jun. 2010; NHMUK CM13 • 1 ㅇ adult (CW $54.4 \mathrm{~mm}$ ); same collection data as for preceding; NHMUK CM14 1 1 subadult $(\mathrm{CW} 44.1 \mathrm{~mm})$; same collection data as for preceding; NHMUK CM21 • 1 adult (CW 54.8 mm); Lake Malawi, NW coast near Nkhata Bay; 1961; Sweeney leg.; NHMUK 2011.1509 • 1 q subadult (CW 32.7 mm); Lake Malawi, Cape Maclear; 17 Jun. 2010; M.

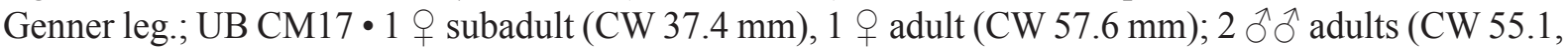
$54.9 \mathrm{~mm}$ ); same collection data as for preceding; UB CM22, UB CM11, UB CM20, UB CM12 • 1 ㅇ adult (CW $57.1 \mathrm{~mm}), 1$ q subadult (CW $33.1 \mathrm{~mm}$ ); same collection data as for preceding; $26 \mathrm{Jun}$. 2010; UB CM10, UB CM5 • 1 ô subadult (CW $49.2 \mathrm{~mm}$ ); same collection data as for preceding; $21 \mathrm{Jun}$. 2010; UB CM4 $\bullet 1$ subadult (CW $48.3 \mathrm{~mm}$ ); same collection data as for preceding; UB CM9 1 \& subadult (CW $46.7 \mathrm{~mm}$ ); same collection data as for preceding; UB CM15 1 q subadult (CW $35.4 \mathrm{~mm}$ ); same collection data as for preceding; UB CM16 1 ㅇ subadult (CW $45.4 \mathrm{~mm}$ ); same collection data as for preceding; UB CM24 1 त adult (CW $59.4 \mathrm{~mm}$ ); same collection data as for preceding; UB CM7 • 2 우 우 adults (CW 55.4, $54.4 \mathrm{~mm}), 2$ 우 subadults (CW 44.9, $45.9 \mathrm{~mm}$ ); same collection data as for preceding; UB CM7 • 1 § adult; same collection data as for preceding; 26 Jun. 2010; R. Bills leg.; AMG CAW 467A.

\section{Redescription}

Carapace height equal to front width $(\mathrm{CH} / \mathrm{FW} \mathrm{1.0)}$; carapace length $2.5 \times$ front width $(\mathrm{CL} / \mathrm{FW} 2.5)$; carapace width $3.5 \times$ front width $(\mathrm{CW} / \mathrm{FW} 3.5)$; exorbital tooth large forward-pointing spine; exorbital tooth lateral margin not angled, in line with midline axis of carapace, curving slightly inward (concave) before meeting postfrontal crest; epibranchial tooth pointed, as large as other teeth lining anterolateral margin (Figs 4E, 10A). Anterolateral margin posterior to epibranchial tooth curving strongly outward (Fig. 4E); postfrontal crest distinct, completely traversing carapace between epibranchial teeth; posterior surface of carapace with deep urogastric grooves; carapace branchiostegal wall divided by vertical pleural suture into suborbital and subhepatic regions, both smooth with sparse granules, pterygostomial region smooth (Fig. 10B); epistomial tooth prominent, granulated, V-shaped. Mandible palp comprising 2 articles; terminal article single, undivided, with setae (but no hard flap) at junction between articles. Third maxillipeds filling entire oral field, except for transversely ovate respiratory openings at superior lateral corners; exopod with long flagellum; ischium with deep vertical sulcus. 
Thoracic sternal sulcus S3/4 deep, completely traversing sternum; episternal sulci S4/E4, S5/E5, S6/ E6, and S7/E7 distinct.

Major chela dactylus (moveable finger) and pollex of propodus (fixed finger) thick, broad, leaving long interspace between fingers when closed; both fingers with 3 large teeth unfused proximally, several medium-sized teeth distally (Fig. 6G-H); cheliped carpus inner margin with two large subequal forwardpointing spines (Fig. 7D); cheliped merus inner lower margin with spine-like tooth distally; P5 carpus, propodus, and dactylus all slender, distinctly elongated; P2-5 dactyli elongated, tapering to pointed tip, each bearing 4 rows of downward-pointing, short, sharp spines.

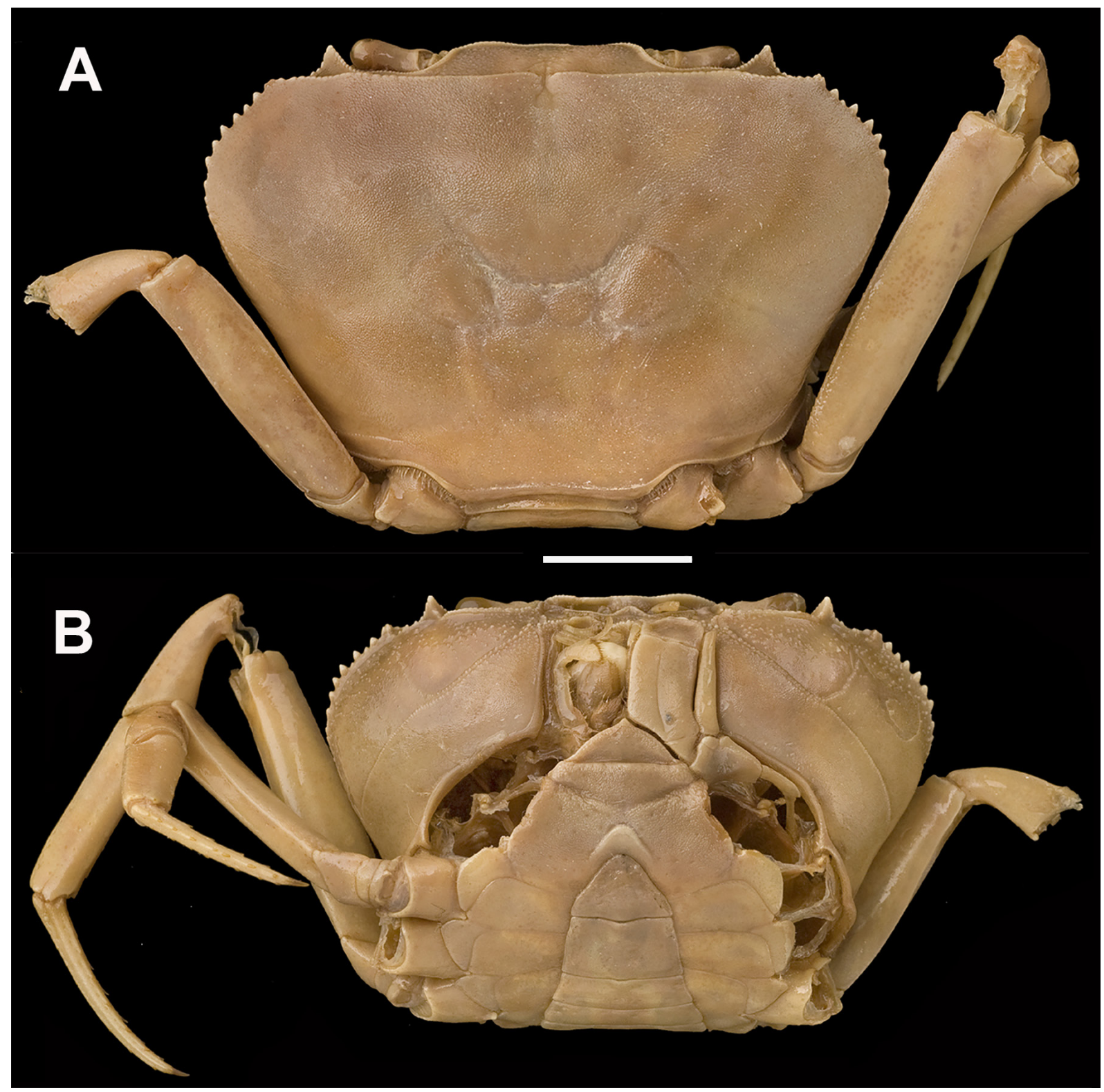

Fig. 10. Potamonautes orbitospinus (Cunnington, 1907), lectotype, adult, $\widehat{\partial}$, from Nkhata Bay, Lake Malawi, Malawi, CW 56.9 mm (NHMUK 1908.1.31.27). A. Entire animal, dorsal view. B. Entire animal, ventral view. Scale bar $=11.9 \mathrm{~mm}$. Photographs by Phillip Crabb, NHMUK. 
Pleon of male slim, triangular, telson narrow triangle with rounded apex, pleomeres Al-6 quadrate. G1 TA proximal third straight, not widened, margins parallel, at midpoint bent sharply outward at $90^{\circ}$ angle to longitudinal axis of G1 SA; G1 TA (Fig. 12A-C, E-G) conspicuously widened by high, rounded dorsal lobe (as wide as TA width at TA-SA junction); tip distinctly curved upwards; G1 SA at junction with G1

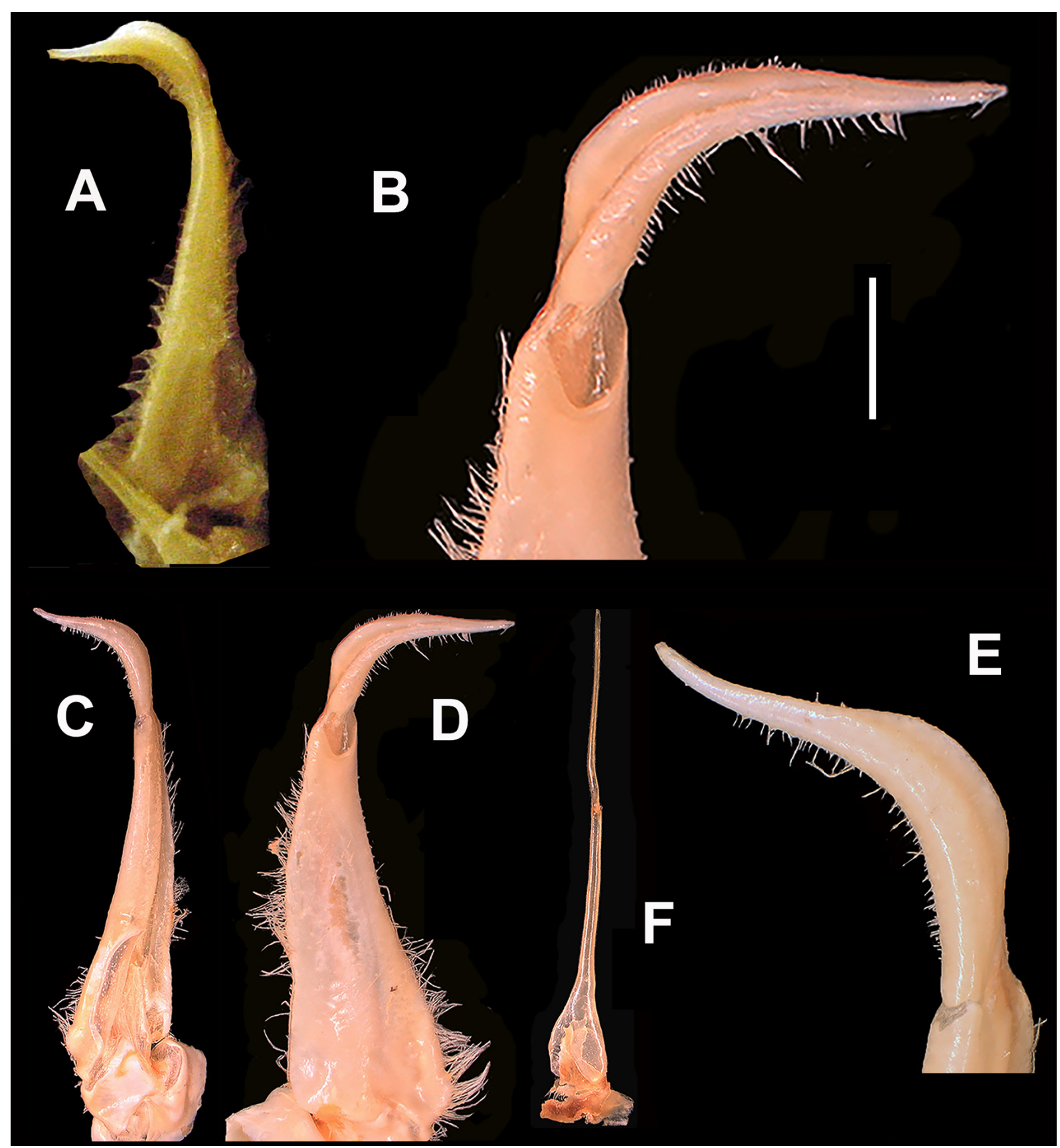

Fig. 11. A. Potamonautes kisangani sp. nov., holotype, adult, $\widehat{\partial}, \mathrm{CW} 60.5 \mathrm{~mm}$, from Kisangani, Democratic Republic of the Congo (USNM 98944). G1, ventral view. - B-F. P. amosae sp. nov.,

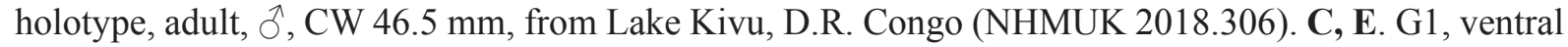
view. B, D. G1, dorsal view. F. G2, ventral view. Scale bar: A, C-D = $3.0 \mathrm{~mm}$; B $=3.1 \mathrm{~mm}$; E = 1.2 $\mathrm{mm} ; \mathrm{F}=1.3 \mathrm{~mm}$. 
TA with horizontal margin on ventral side, U-shaped indentation filled by conspicuous dorsal membrane on dorsal side. G2 TA: long, flagellum-like (Fig. 12D, H). Margins of G1 TA, SA lined by setae.

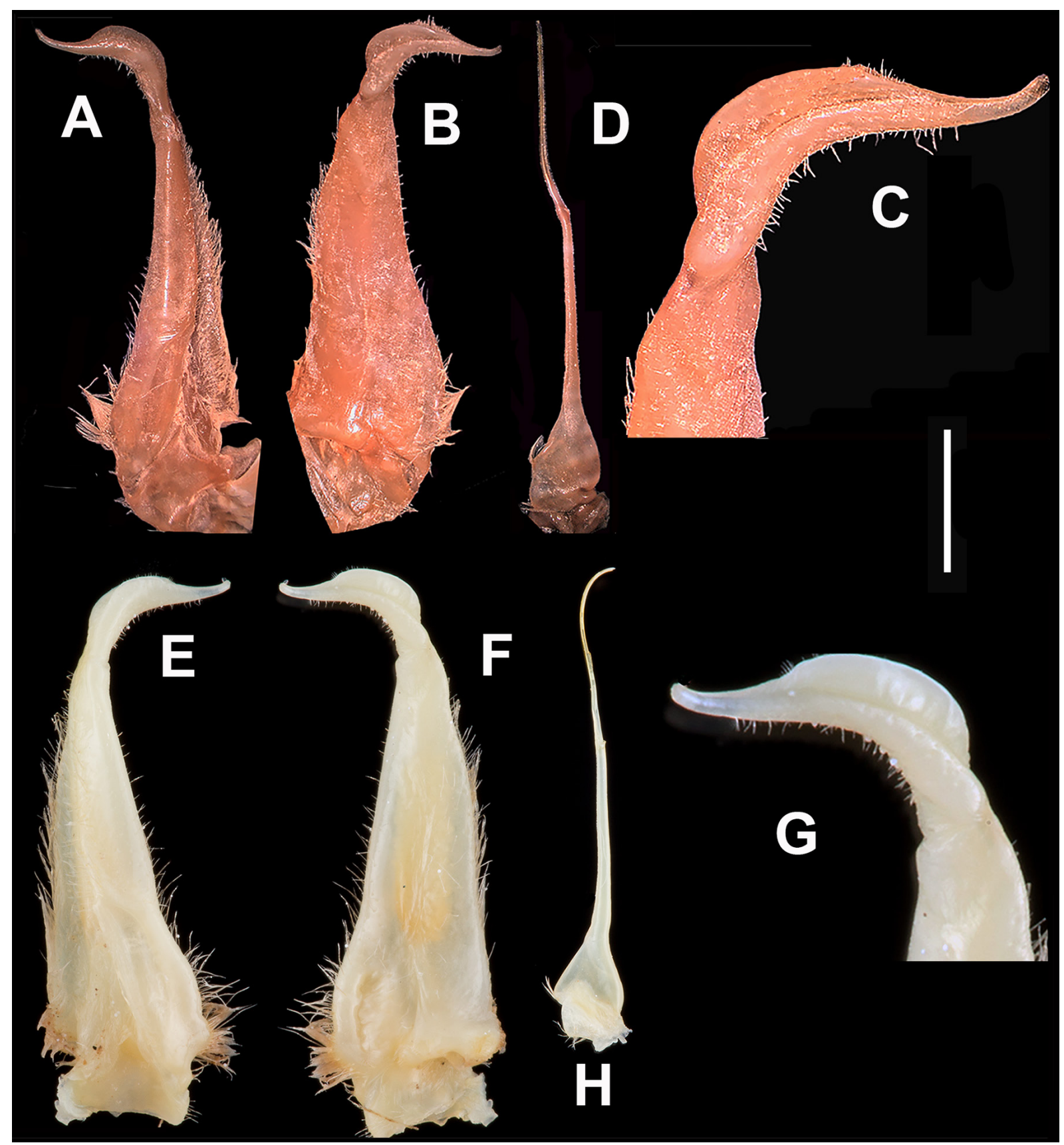

Fig. 12. Potamonautes orbitospinus (Cunnington, 1907). A-D. Lectotype, adult, $\widehat{\jmath}, \mathrm{CW} 56.9 \mathrm{~mm}$, from Nkhata Bay, Lake Malawi, Malawi (NHMUK 1908.1.31.27). A. G1, ventral view. B-C. G1, dorsal view. D. G2, ventral view. E-H. Adult, ô, Cape Maclear, Lake Malawi, Malawi (AMG CAW 467A). E. G1, ventral view. F-G. G1, dorsal view. H. G2, ventral view. Scale bar: A-B, E-F = $3 \mathrm{~mm}$; C, G = $1.3 \mathrm{~mm} ; \mathrm{D}, \mathrm{H}=1.2 \mathrm{~mm}$. 


\section{Size}

Large species, pubertal molt starting around CW $53 \mathrm{~mm}$ (largest adult male CW $56.9 \mathrm{~mm}$, largest adult female CW $53.9 \mathrm{~mm}$ ).

\section{Colour}

The carapace surface and branchiostegal walls of living specimens are deep blue, and are especially bright in newly-hardened specimens (Fig. 13). There are distinct white outlines marking the postfrontal crest, anterolateral margins, frontal margin, orbital margins, exorbital teeth, epistome, and the third maxilliped ischium and merus. The thoracic sternum is pinkish blue/grey and cream, and the arthrodial membranes on the inner side of the joints between the coxae and the basis of the chelipeds and P2-5 are cream.

\section{Distribution}

Potamonautes orbitospinus is abundant and widely distributed throughout Lake Malawi (Fig. 2) and has not been recorded from outside of the lake.

\section{Ecology}

Lake Malawi is the southernmost Great Lake in the East African Rift system and lies in 3 countries: Malawi, Mozambique, and Tanzania. The Ruhuhu River in Tanzania flows west into the northeastern part of Lake Malawi while the Shire River drains south out of the lake and is a tributary of the Zambezi River.

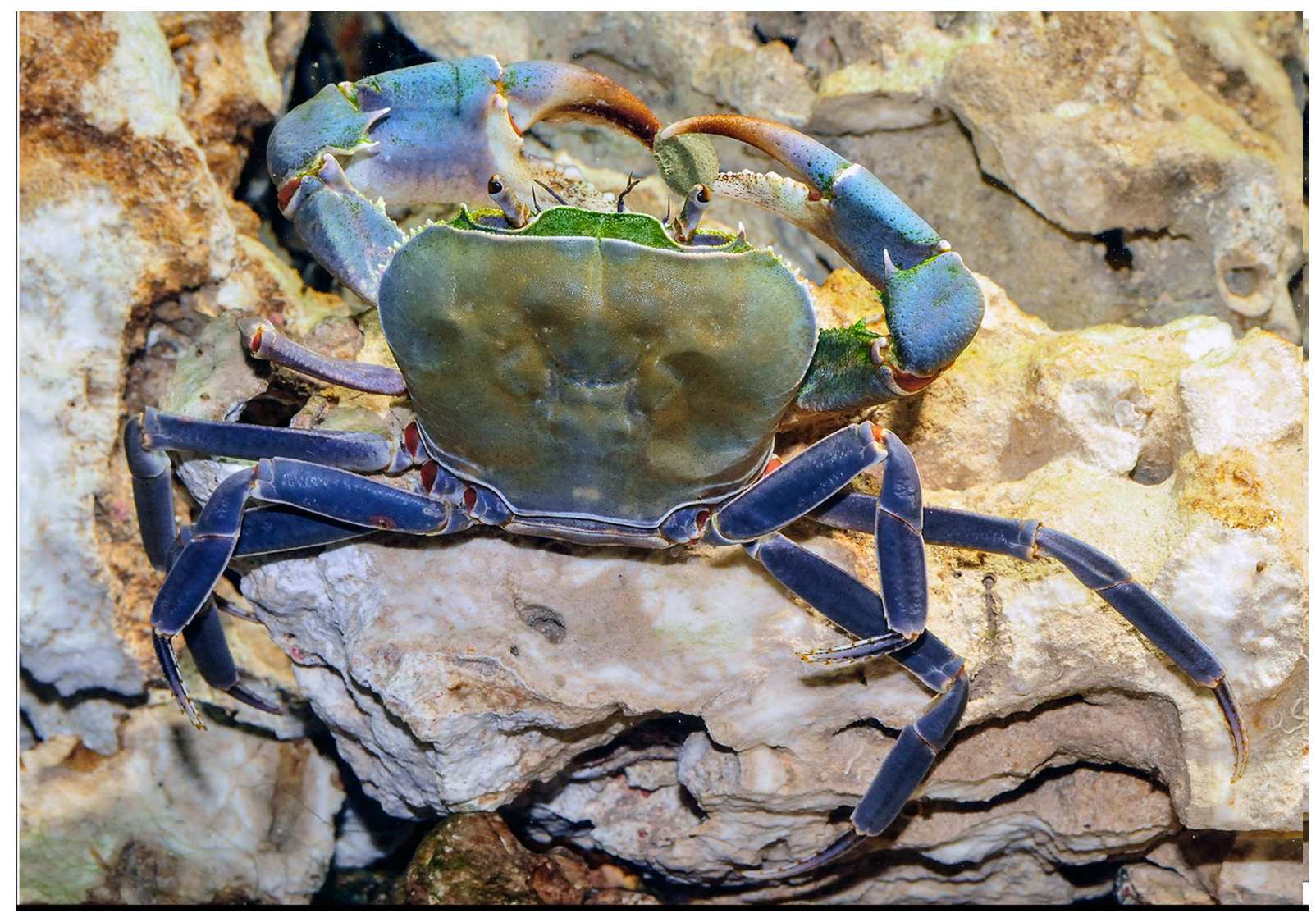

Fig. 13. Potamonautes orbitospinus (Cunnington, 1907), living specimen from Lake Malawi, Malawi. Photograph Oliver-Mengedoht.de/Panzerwelten.de. 
In 1904, Cunnington and his assistants collected the first known specimens of P. orbitospinus from the waters of Lake Malawi itself, noting that some specimens were found on the beach (Cunnington 1907). The specimens reported on here are all restricted to Lake Malawi, and this species is a lake specialist that has never been collected in the rivers of the drainage basin that flow into the lake.

\section{Conservation status}

An IUCN conservation assessment of $P$. orbitospinus has not yet been carried out. The species is known from a large number of specimens from 16 localities all in Lake Malawi $\left(29600 \mathrm{~km}^{2}\right)$. Given that its estimated extent of occurrence (EOO) is more than $21100 \mathrm{~km}^{2}$, and that no specific threats are known, it would probably be assessed as Least Concern. It is significant that the population levels of P. orbitospinus are sufficient to be regularly caught as bycatch in local fisheries in Lake Malawi, and this species is also captured to supply a steady demand by the global aquarium trade.

\section{Remarks}

The recognition of $P$. orbitospinus and $P$. lirrangensis s. str. as valid species returns to the original taxonomic situation over 110 years ago when they were first described from two widely separated locations (Rathbun 1904; Cunnington 1907). Chace (1942) also treated P. lirrangensis and P. orbitospinus as valid species, but Bott (1955), Reed \& Cumberlidge (2006) and Cumberlidge \& Meyer (2011) considered Potamon (Potamonautes) orbitospinus to be a junior synonym of Potamonautes lirrangensis s. lat. The result has been that the available descriptions and distribution maps of Potamonautes lirrangensis $\mathrm{s}$. lat. (Reed \& Cumberlidge 2006: fig. 177) incorrectly combine characters and localities of $P$. lirrangensis s. str. from the Congo River with those of P. orbitospinus from Lake Malawi, and P. amosae sp. nov. from Lake Kivu and Kigoma District near Lake Tanganyika.

Potamonautes orbitospinus is recognised here based on characters of the lectotype described by Cunnington (1907) from Lake Malawi as well as other comparable material from this lake. The redescription includes new taxonomically important characters because although the description by Cunnington (1907) of P. orbitospinus was based on an adult male, he did not illustrate the first gonopod or sternal characters of the type specimen. See concluding remarks below for comparisons with other superficially similar species.

The combined phylogeny based on mitochondrial 16S rRNA and the nuclear coding gene Histone $\mathrm{H} 3$ (Fig. 14) includes a specimen from Thumbi West Island near Cape Maclear in southern Lake Malawi (GenBank DQ203209, DQ203235), alongside eight other specimens from Cape Maclear and Chiofu on the east coast of Lake Malawi. The phylogeny suggests a monophyletic clade for $P$. orbitospinus from Lake Malawi, separate from the clade for P. amosae sp. nov. (Fig. 14).

A specimen identified as P. lirrangensis s. lat. from 'Uazua' in the Zambian part of Lake Tanganyika (POlirrangensisZAM31; Marijnissen et al. 2006) has a partial 16S sequence (DQ203237) with high similarity (99\%) to a specimen of P. orbitospinus from Lake Malawi (POlirrangensisMAL27; DQ203235; Marijnissen et al. 2006). This same specimen (POlirrangensisZAM31), however, has a partial 12S sequence (DQ203211) which has only 97\% similarity to POlirrangensisMAL27 (DQ203209). This may indicate that $P$. orbitospinus shares a close evolutionary affinity to specimens within Lake Tanganyika, but further sampling is required to determine the evolutionary relationships of these two groups.

Kochey et al. (2017) carried out a molecular study of the Malawi blue crab (which they identified as $P$. lirrangensis s. lat.) that found the morphologically similar populations in Lake Malawi to be equally close genetically, and confirmed that the lake hosts only a single species of freshwater crab (here identified as P. orbitospinus). Those authors also found that the blue crab populations in Lake Malawi had only moderate haplotype diversity and low levels of nucleotide diversity for two mitochondrial 
loci (NADH dehydrogenase subunit 1 (ND1) and cytochrome b (CytB) (Kochey et al. 2017). The lack of divergence of blue crab populations in Lake Malawi and the morphological similarity of specimens found in different parts of the lake suggests a recent colonisation (Kochey et al. 2017).

\section{Discussion}

The results of the present molecular study (Fig. 14) support the recognition of $P$. orbitospinus from Lake Malawi and of $P$. amosae sp. nov. from Lake Kivu and Tanzania. The 4 taxa formerly assigned to

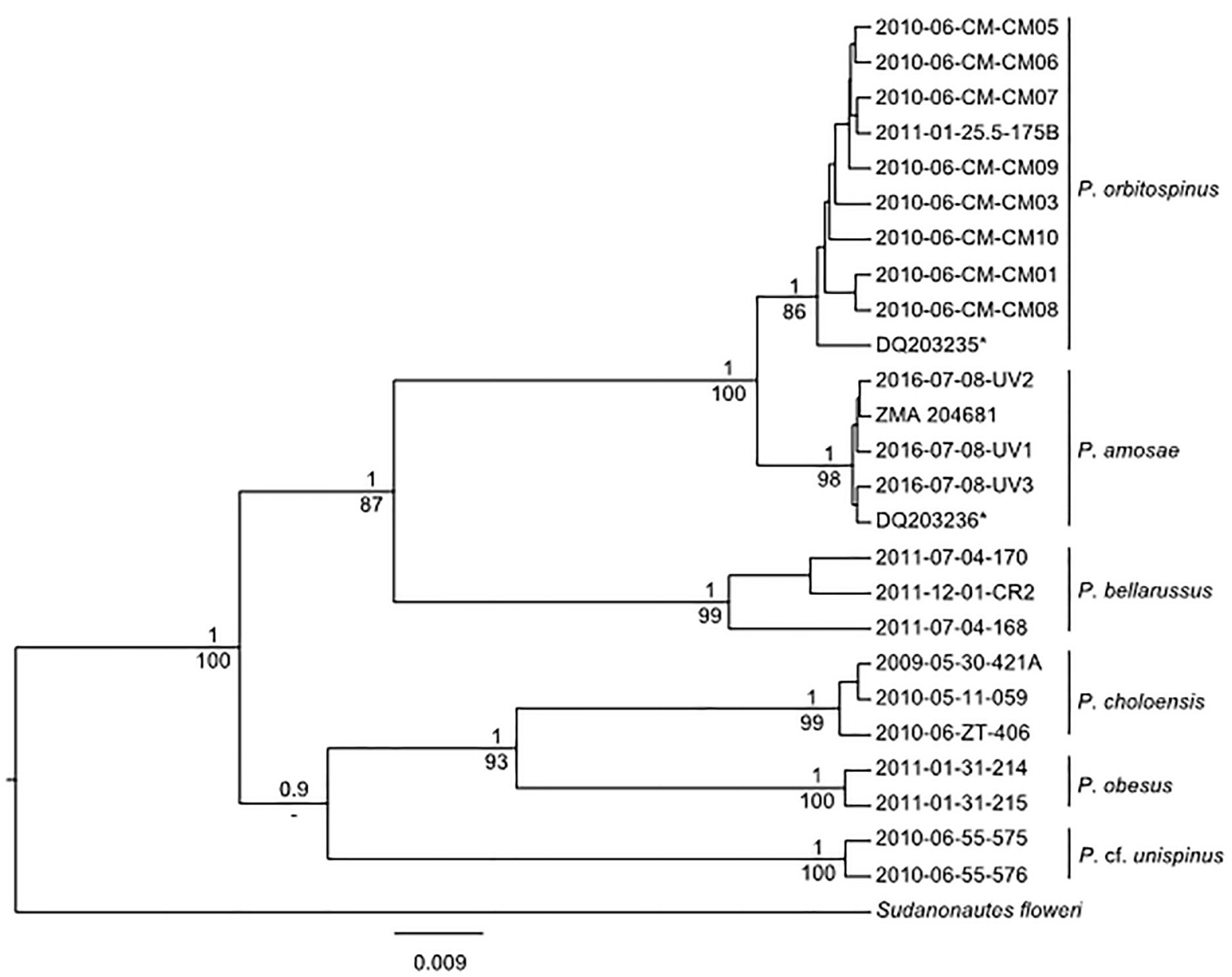

Fig. 14. Phylogenetic relationships of species of African freshwater crabs included in the present study. Potamonautes orbitospinus (Cunnington, 1907) and P. amosae sp. nov. were both formerly included in the Potamonautes lirrangensis (Rathbun, 1904) s. lat. species complex. The analysis combines 16SrRNA (489 bp alignment) and Histone 3 sequences (290 bp alignment). Numbers above branches indicate Bayesian Inference ( $\sim \mathrm{BI})$ posterior probability support values, and numbers below branches indicate Maximum likelihood (ML) bootstrap support values. Only intraspecific node support values are shown for clarity. '-' indicates the node was not supported by ML analysis. Codes on the branch tips indicate either isolate numbers or *Genbank accession numbers (Table 2). Other species shown on the tree (P. bellarussus Daniels, Phiri \& Bayliss, 2014, P. choloensis Chace, 1953, P. obesus A. MilneEdwards, 1868, and $P$. cf. unispinus Stewart \& Cook, 1998) have a distribution that overlaps with that of the focal species (P. lirrangensis s. lat.). The outgroup species is Sudanonautes floweri de Man, 1901 from Cameroon and Gabon. The scale bar indicates genetic distance. 
P. lirrangensis s. lat., namely $P$. lirrangensis $\mathrm{s}$. str. from Liranga, $P$. kisangani $\mathrm{sp}$. nov. from Kisangani, P. orbitospinus from Lake Malawi, and P. amosae sp. nov. from Lake Kivu and Tanzania, can be distinguished by the suite of morphological characters provided earlier.

The present study has resolved a long-standing controversy regarding the taxonomic identity of the Malawi blue crab, which was formerly identified as P. lirrangensis s. lat., and, after 65 years, is now again recognized as $P$. orbitospinus. In addition, the identity of the largest species of freshwater crab found in Lake Kivu is recognized here as $P$. amosae sp. nov. and this is grouped with populations of large crabs from the Lake Tanganyika drainage in Tanzania and the D.R. Congo. Finally, a better understanding of the taxonomic status of P. lirrangensis s. str. from Liranga and $P$. kisangani sp. nov. from Kisangani await further collections from the largely unexplored Middle Congo River.

\section{Acknowledgements}

We thank the staff of the Tanzania Fisheries Research Institute for contributions to fieldwork. Funding was provided by the Royal Society-Leverhulme Trust Africa Awards AA100023 and AA130107. We thank M. Dallas, L. Worrall, D. Kyriaki, S. Woolven, J. Champ and S. De Belder for contributions to the molecular laboratory work. We thank the staff of the Tanzania Fisheries Research Institute and J. Swanstrom for their contributions to fieldwork. The photographs of the lectotype of $P$. orbitospinus (Figs 4E, 5C, 6G-H, 7D, 10A-B, 12A-D) were taken by Phillip Crabb, NHMUK, London, and the photograph of a living specimen of P. orbitospinus from Lake Malawi (Fig. 13) was taken by Oliver Mengedoht of Oliver-Mengedoht.de/Panzerwelten.de. Finally, photographs Figs 12E-H of P. orbitospinus were taken by Theo Busschau of Stellenbosch University, South Africa.

\section{Conflicts of interest}

The authors declare no conflicts of interest.

\section{References}

Abell R., Thieme M.L., Revenga C., Bryer M., Kottelat M., Bogutskaya N., Coad B., Mandrak N., Balderas S.C., Bussing W., Stiassny M.L.J., Skelton P., Allen G.R., Unmack P., Naseka A., Ng R., Sindorf N., Robertson J., Armijo E., Higgins J.V., Heibel T.J., Wikramanayake E., Olson D., López H.L., Reis R.E., Lundberg J.G., Sabaj Pérez M.H. \& Petry P. 2008. Freshwater ecoregions of the world: a new map of biogeographic units for freshwater biodiversity conservation. BioScience 58: 403-414. https://doi.org/10.1641/b580507

Balss H. 1914. Decapod Crustaceen von den Guinea-Inseln, Sud-Kamerun und dem Congogebiet. Ergebnisse der zweiten Deutschen Zentral-Africa-Expedition 1910-1911 unter Fühung AldolfFriedrichs, Herzog der Meeresfauna Westafricas (Zoologie) 1: 97-108.

Balss H. 1929. Ueber ostafrikanische Potamonidae (Decapoda). Mit Anhang; Potamoniden von Madagascar. Zoologische Jahrbücher, Abteilung für Systematik, Geographie und Biologie der Thiere 58: 339-358.

Balss H. 1936. Beiträge zur Kenntnis der Potamonidae (Süßwasserkrabben) des Kongogebietes. Revue zoologique et botanique d'Afrique 28: 165-204.

Bachman S., Moat J., Hill A.W., de la Torre J. \& Scott B. 2011. Supporting Red List threat assessments with GeoCAT: geospatial conservation assessment tool. ZooKeys 150: 117-126.

https://doi.org/10.3897/zookeys.150.2109

Bott R. 1955. Die Süßwasserkrabben von Afrika und ihre Stammesgeschichte. Annales du Musée royal du Congo belge 1 (3): 209-352. 
Bouckaert R., Vaughan T.G., Barido-Sottani J., Duchêne S., Fourment M., Gavryushkina A., Heled J., Jones G., Kühnert D., De Maio N., Matschiner M., Mendes F.K., Müller N.F., Ogilvie H.A., du Plessis L., Popinga A., Rambaut A., Rasmussen D., Siveroni I., Suchard M.A., Wu C.-H., Xie D., Zhang C., Stadler T. \& Drummond A.J. 2019. BEAST 2.5: an advanced software platform for Bayesian evolutionary analysis. PLoS Computational Biology 15: e1006650.

https://doi.org/10.1371/journal.pcbi.1006650

Capart A. 1952. Crustacés, décapodes, brachyures. In: Exploration hydrobiologique du Lac Tanganyika (1946-1947), Résultats scientifiques 3 (3): 41-67. Institut royal des Sciences naturelles, Brussels.

Capart A. 1954. Révision des types des espèces de Potamonidae de l'Afrique tropicale conserves au Muséum d'Histoire Naturelle de Paris. In: Volume Jubilaire de Victor Van Strallen, Director de l'Institut royal des Sciences naturelles de Belgique, 1925-1934 2: 819-847. Institut royal des Sciences naturelles, Brussels.

Chace F.A. 1942. Scientific results of a fourth expedition to forested areas in eastern Africa, III: Decapod Crustacea. Bulletin of the Museum of Comparative Zoology at Harvard College 91: 185-233.

Chernomor O., von Haeseler A. \& Minh B.Q. 2016. Terrace aware data structure for phylogenomic inference from supermatrices. Systematic Biology 65: 997-1008. https://doi.org/10.1093/sysbio/syw037

Colgan D.J., McLauchlan A., Wilson G.D.F., Livingston S.P., Edgecombe G.D., Macaranas J., Cassis G. \& Gray M.R. 1998. Histone H3 and U2 snRNA DNA sequences and arthropod molecular evolution. Australian Journal of Zoology 46: 419-437. https://doi.org/10.1071/zo98048

Coulter G.W. (ed.). 1991. Lake Tanganyika and its Life. British Museum (Natural History) and Oxford University Press, Oxford.

Cumberlidge N. 1998. The African and Madagascan freshwater crabs in the Zoologische Staatssammlung, Munich (Crustacea: Decapoda: Brachyura: Potamoidea). Spixiana 21: 193-214.

Cumberlidge N. 1999. The Freshwater Crabs of West Africa, Family Potamonautidae. Faune et Flore tropicales 35, IRD, Paris.

Cumberlidge N. 2018. Potamonautes lirrangensis. The IUCN Red List of Threatened Species 2018: e.T44201A114989565. https://doi.org/10.2305/IUCN.UK.2018-1.RLTS.T44201A114989565.en

Cumberlidge N. \& Meyer K.S. 2011. The freshwater crabs of Lake Kivu (Crustacea: Decapoda: Brachyura: Potamonautidae). Journal of Natural History 45 (29-30): 1835-1837.

https://doi.org/10.1080/00222933.2011.562618

Cunnington W.A. 1907. Zoological results of the Third Tanganyika Expedition, conducted by Dr. W.A. Cunnington, 1904-1905. - Report on the brachyurous Crustacea. Proceedings of the Zoological Society of London 1907: 258-276. https://doi.org/10.1111/j.1096-3642.1907.tb01815.x

Daniels S.R., Cumberlidge N., Pérez-Losada M., Marijnissen S.A.E. \& Crandall K.A. 2006. Evolution of Afrotropical freshwater crab lineages obscured by morphological convergence. Molecular Phylogenetics and Evolution 40: 227-235. https://doi.org/10.1016/j.ympev.2006.02.022

Daniels S.R., Phiri E.E., Klaus S., Albrecht C. \& Cumberlidge N. 2015. Multilocus phylogeny of the Afrotropical freshwater crab fauna reveals historical drainage connectivity and transoceanic dispersal since the Eocene. Systematic Biology 64: 549-567. https://doi.org/10.1093/sysbio/syv011

Hoang D.T., Chernomor O., von Haeseler A., Minh B.Q. \& Vinh L.S. 2018. UFBoot2: improving the ultrafast bootstrap approximation. Molecular Biology and Evolution 35: 518-522. https://doi.org/10.1093/molbev/msx281 
Kochey J.K., Daniels S.R., Plagge C., Mehrabi S., Hartmann L., Schrenk F., Plath M. \& Klaus S. 2017. Genetic differentiation of the Malawi blue crab reflects Pleistocene desiccation of Lake Malawi (Brachyura, Potamonautidae: Potamonautes lirrangensis (Rathbun, 1904)). Hydrobiologia 843: 1-11. https://doi.org/10.1007/s10750-017-3292-2

Marijnissen S.A.E., Michel E., Daniels S.R., Erpenbeck D., Menken S.B.J. \& Schram F.R. 2006. Molecular evidence for recent divergence of Lake Tanganyika endemic crabs (Decapoda: Platythelphusidae). Molecular Phylogenetics and Evolution 40 (2): 628-634. https://doi.org/10.1016/j.ympev.2006.03.025

Minh B.Q., Schmidt H.A., Chernomor O., Schrempf D., Woodhams M.D., von Haeseler A. \& Lanfear R. 2020. IQ-TREE 2: new models and efficient methods for phylogenetic inference in the genomic era. Molecular Biology and Evolution 37: 1530-1534. https://doi.org/10.1093/molbev/msaa015

Mvogo Ndongo P.A., Schubart C.D., Von Rintelen T., Tamesse J.L. \& Cumberlidge N. 2017. Morphological and molecular evidence for a new species of freshwater crab of the genus Sudanonautes Bott, 1955 (Brachyura: Potamoidea: Potamonautidae) from Cameroon, with notes on its ecology. Zootaxa 4242 (1): 161-173. https://doi.org/10.11646/zootaxa.4242.1.8

Ng P.K.L., Guinot D. \& Davie P. 2008. Systema Brachyuorum: Part I. An annotated checklist of extant brachyuran crabs of the world. Raffles Bulletin of Zoology, Supplement 17: 1-286.

Palumbi S.R., Martin A., Romano S., McMillan W.O., Stice L. \& Grabowski G. 1991. The Simple Fool's Guide to PCR, version 2.0. University of Hawaii, Honolulu.

Rathbun M.J. 1904. Les crabes d'eau douce (Potamonidae). Nouvelles Archives du Muséum d'Histoire naturelle, Série 4 6: 255-312. Available from https://www.biodiversitylibrary.org/part/49665 [accessed 11 Mar. 2021].

Rathbun M.J. 1905. Les crabes d'eau douce (Potamonidae). Nouvelles Archives du Muséum d'Histoire naturelle, Série 4 7: 159-322.

Available from https://www.biodiversitylibrary.org/item/112422\#page/179/mode/1up [accessed 11 Mar. 2021].

Rathbun M.J. 1921. The brachyuran crabs collected by the American Museum Congo Expedition 19091915. (Ecological notes by H. Lang). Bulletin of the American Museum of Natural History 43: 397-468. Available from http://hdl.handle.net/2246/1016 [accessed 11 Mar. 2021].

Reed S.K. \& Cumberlidge N. 2006. Taxonomy and biogeography of the freshwater crabs of Tanzania, East Africa (Brachyura: Potamoidea: Potamonautidae, Platythelphusidae, Deckeniidae). Zootaxa 1262: 1-139. https://doi.org/10.11646/zootaxa.1262.1.1

Thieme M.L., Abell R., Burgess N., World Wildlife Fund, Lehner B., Dinerstein E,, Olson D., Teugels G., Kamdem-Toham A., Stiassny M.L.J.S. \& Skelton P. 2005. Freshwater Ecoregions of Africa and Madagascar: A Conservation Assessment. Island Press, Washington, DC.

Thompson J.D., Gibson T.J. \& Higgins D.G. 2003. Multiple sequence alignment using ClustalW and ClustalX. Current Protocols in Bioinformatics 1: 2-3. https://doi.org/10.1002/0471250953.bi0203s00

Vaidya G., Lohman D.J. \& Meier R. 2011. SequenceMatrix: concatenation software for the fast assembly of multi-gene datasets with character set and codon information. Cladistics 27: 171-180.

https://doi.org/10.1111/j.1096-0031.2010.00329.x

Manuscript received: 17 July 2020

Manuscript accepted: 17 January 2021

Published on: 13 April 2021 
Topic editor: Rudy Jocqué

Desk editor: Pepe Fernández

Printed versions of all papers are also deposited in the libraries of the institutes that are members of the EJT consortium: Muséum national d'histoire naturelle, Paris, France; Meise Botanic Garden, Belgium; Royal Museum for Central Africa, Tervuren, Belgium; Royal Belgian Institute of Natural Sciences, Brussels, Belgium; Natural History Museum of Denmark, Copenhagen, Denmark; Naturalis Biodiversity Center, Leiden, the Netherlands; Museo Nacional de Ciencias Naturales-CSIC, Madrid, Spain; Real Jardín Botánico de Madrid CSIC, Spain; Zoological Research Museum Alexander Koenig, Bonn, Germany; National Museum, Prague, Czech Republic. 